Portland State University

PDXScholar

$4-11-1994$

\title{
Studies on the Role of Cellular Factor, YY1, in Herpes Simplex Virus Type 1 Late Gene Expression
}

Xuehui Liu

Portland State University

Follow this and additional works at: https://pdxscholar.library.pdx.edu/open_access_etds

Part of the Biology Commons

Let us know how access to this document benefits you.

Recommended Citation

Liu, Xuehui, "Studies on the Role of Cellular Factor, YY1, in Herpes Simplex Virus Type 1 Late Gene Expression" (1994). Dissertations and Theses. Paper 4856.

https://doi.org/10.15760/etd.6732

This Thesis is brought to you for free and open access. It has been accepted for inclusion in Dissertations and Theses by an authorized administrator of PDXScholar. Please contact us if we can make this document more accessible: pdxscholar@pdx.edu. 


\section{THESIS APPROVAL}

The abstract and thesis of Xuehui Liu for the Master of Science in Biology were presented April 11, 1994, and accepted by the thesis committee and department.

\section{COMMITTEE APPROVALS:}

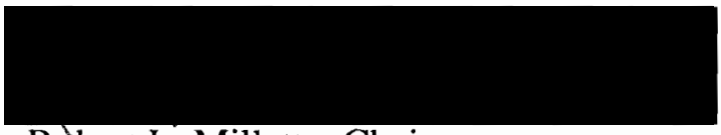

$$
\text { Robert L. Millette, Chair }
$$
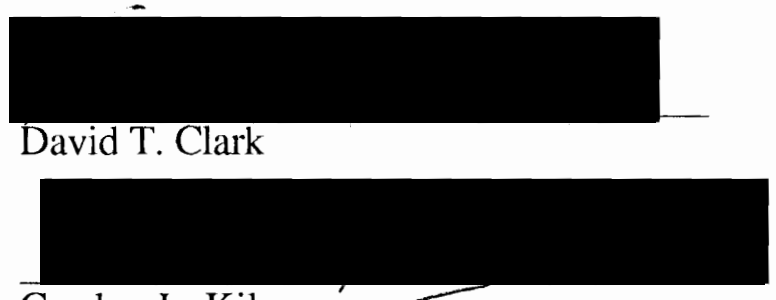

Gordon L. Kilgour

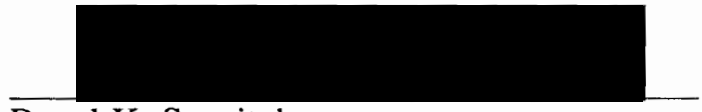

Pavel K. Smejtek

DEPARTMENT APPROVAL:

Robert O. Tinnin, Chair,

Department of Biology

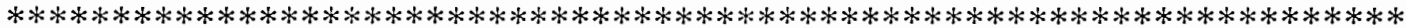

\section{ACCEPTED FOR PORTLAND STATE UNIVERSITY BY THE LIBRARY}

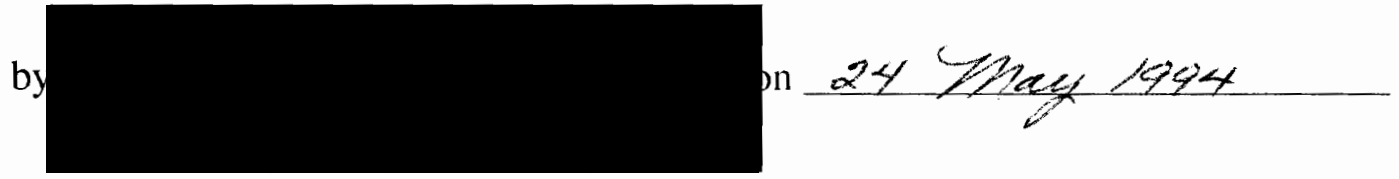




\begin{abstract}
An abstract of the thesis of Xuehui Liu for the Master of Science in Biology presented April 11, 1994.

Title: Studies on the Role of Cellular Factor, YY1, in Herpes Simplex Virus Type 1 Late Gene Expression
\end{abstract}

The herpes simplex virus 1 (HSV1) VP5 gene codes for the major viral capsid protein. Understanding of the mechanism of how the VP5 gene is regulated in host cells will help us to understand the molecular action of the HSV1 life cycle and its interplay with the host cell gene expression machinery (transcription and translation ). This may ultimately provide scientific bases for both better prevention and cure of HSV 1 caused diseases. Previous work from Dr. Robert L. Millette's laboratory has indicated that a 164 base pair region of the VP5 promoter gene could activate the transcription of an attached reporter gene ( bacteria CAT gene ). Furthermore, a 12 bp (GGCCATCTTGAA) cis-acting element situated within the $164 \mathrm{bp}$ promoter region was required for the promoter activity. To understand the function of this cis-element in the regulation of VP5 transcription and to identify the trans-acting factors interacting with this element, gel mobility shift assays were first carried out using the fragment containing the $12 \mathrm{bp}$ site as the probe. A cellular factor, YY1, was found to bind to this site in a sequence specific manner. Based on 
the oligonucleotide competition assays, partial protease digestions, and antibody supershift assays, it became clear that two cellular factors bound to the VP5 promoter. These were related, if not identical, to the previously identified Yin-Yang1 factor (YY 1), and transcription factor the SP1. Site-directed mutagenesis studies indicated that these two factors bind to distinct sites on the $164 \mathrm{bp}$ fragment. Point mutations studies on the 12 bp YY 1 binding site demonstrated that seven of the 12 bp were required for YY 1-DNA complex formation and the first four bp in the $12 \mathrm{bp}$ were very important for VP5 gene regulation. Also, it was found that YY1 performs both positive and negative regulator function in VP5 gene regulation. In conclusion, two cellular transcription factors, YY1 and SP1, play a major role in VP5 gene expression. 


\title{
STUDIES ON THE ROLE OF CELLULAR FACTOR, YY1, IN HERPES SIMPLEX VIRUS TYPE 1 LATE GENE EXPRESSION
}

\author{
by \\ XUEHUI LIU
}

MASTER OF SCIENCE in

Portland State University 1994 


\section{ACKNOWLEDGEMENTS}

I thank all those who assisted me during my graduate program.

I am sincerely grateful to Dr. Robert L. Millette, my advisor, who gave encouragement and assistance throughout this study. Also, I thank him for his supportting and a lot of help.

I would like to thank the members of my committee Drs. David T. Clark, Gordon L. Kilgour and Pavel K. Smejtek.

I would also like to thank LiSA Mills, Len Mills, John Paulson and George, Beaudreau for their kindly help during my graduate study.

Finally, I specially thank my husband, Bin, for his help, his understanding, and his encouragement. 
TABLE OF CONTENTS

PAGE

ACKNOWLEDGEMENTS............................................. iii

LIST OF TABLES................................................. $v$

LIST OF FIGURES............................................. vi

CHAPTER

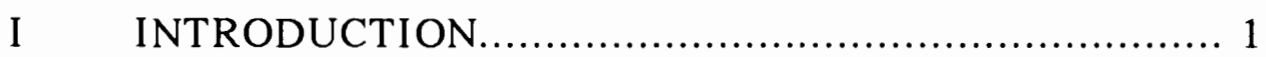

1. General......................................... 1

2. The family of human herpesvirus.................... 2

3. Herpes simplex virus es and their life circle..............8

4. Viral gene expression.............................11

II THE PURPOSE OF THE RESEARCH........................ 14 IN THIS THESIS

III MATERIALS AND METHODS.............................. 18

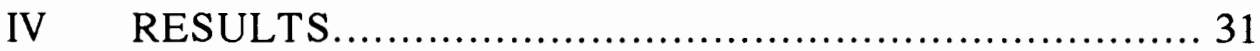

$\mathrm{V} \quad$ DISCUSSION......................................... 53

REFERENCES ...................................................... 59

APPENDIX THE FUNCTIONS OF YY $1 \ldots \ldots \ldots \ldots \ldots \ldots \ldots \ldots \ldots \ldots \ldots \ldots . \ldots 4$ 


\section{LIST OF TABLES}

TABLE

PAGE

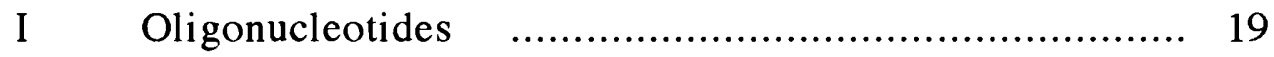

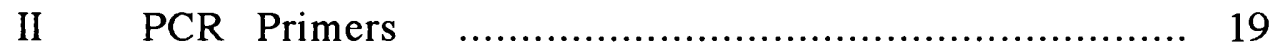

III Gel mobility shift assay I _................................... 35

IV Competition binding assay I .................................. 38

V Transient gene expression I ..................................... 41

VI Gel mobility shift assay II …................................ 47

VII Competition binding assay II f.................................. 49

VIII Transient gene expression II f.................................. 51 


\section{LIST OF FIGURES}

FIGURE

PAGE

I Comparative sizes of virons f............................ 2

II The morphology of herpesviruses $\quad \ldots \ldots \ldots \ldots \ldots \ldots \ldots \ldots \ldots . \ldots \ldots$

III Herpesviridae genes diagrams .............................6

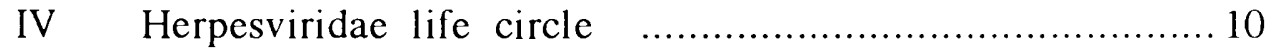

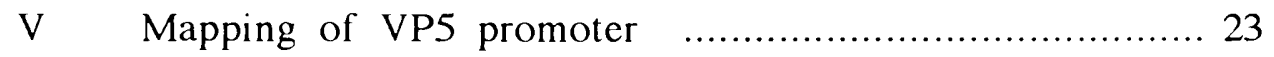

VI Subcloned mutation constructions ............................. 24

VII Gel mobility shift assay I .................................. 34

VIII Competition binding assay I f............................ 37

IX Transient gene expression I............................... 40

X Mechanism of PCR technique ............................ 43a

XI Sequence of point mutations ............................ 43

XII DNA sequencesof point mutation .......................... 44

XIII Gel mobility shift assay II .................................. 46

XIV Competition binding assay II f....................... 48

XV Transient gene expression II ............................ 50

XVI Competition binding assay III ......................... 52 


\section{CHAPTER I}

\section{INTRODUCTION}

\section{General}

Virology as a new individual science is developing very fast. In 1892, Russian chemist Iwanovski discovered the tobacco mosaic virus (24); this was the first human observation in the field of virology. Viruses are the smallest infectious bioorganisms known in the world. Their size comparison with the bacterium Escherichia coli is shown in Figure 1.

One century has passed since the tobacco virus was discovered, and the science of virology has expanded more and more. Transmission by a cell-free filtrate was demonstrated, for foot-and-mouth disease in 1898, for chicken sarcoma in 1911, and viruses infecting bacteria were discovered in $1917(11,24)$. Now, the molecular virology is becoming more and more important in both the basic science research and the clinical application.

Even though viruses are extremely small, they are of great of importance in human disease. Many acute diseases are due to viral infection (49). In some virus infections, not only the incidence of the disease, but also the mortality is very high. In recent years, viral diseases have resulted many social and economic problems in many countries. For example, AIDS (Acquired Immunodeficiency Syndrome), caused by the human immunodeficiency virus (HIV), has taken a heavy toll of lives, and millions of dollars have been spent on its prevention and keeping those affected alive. 


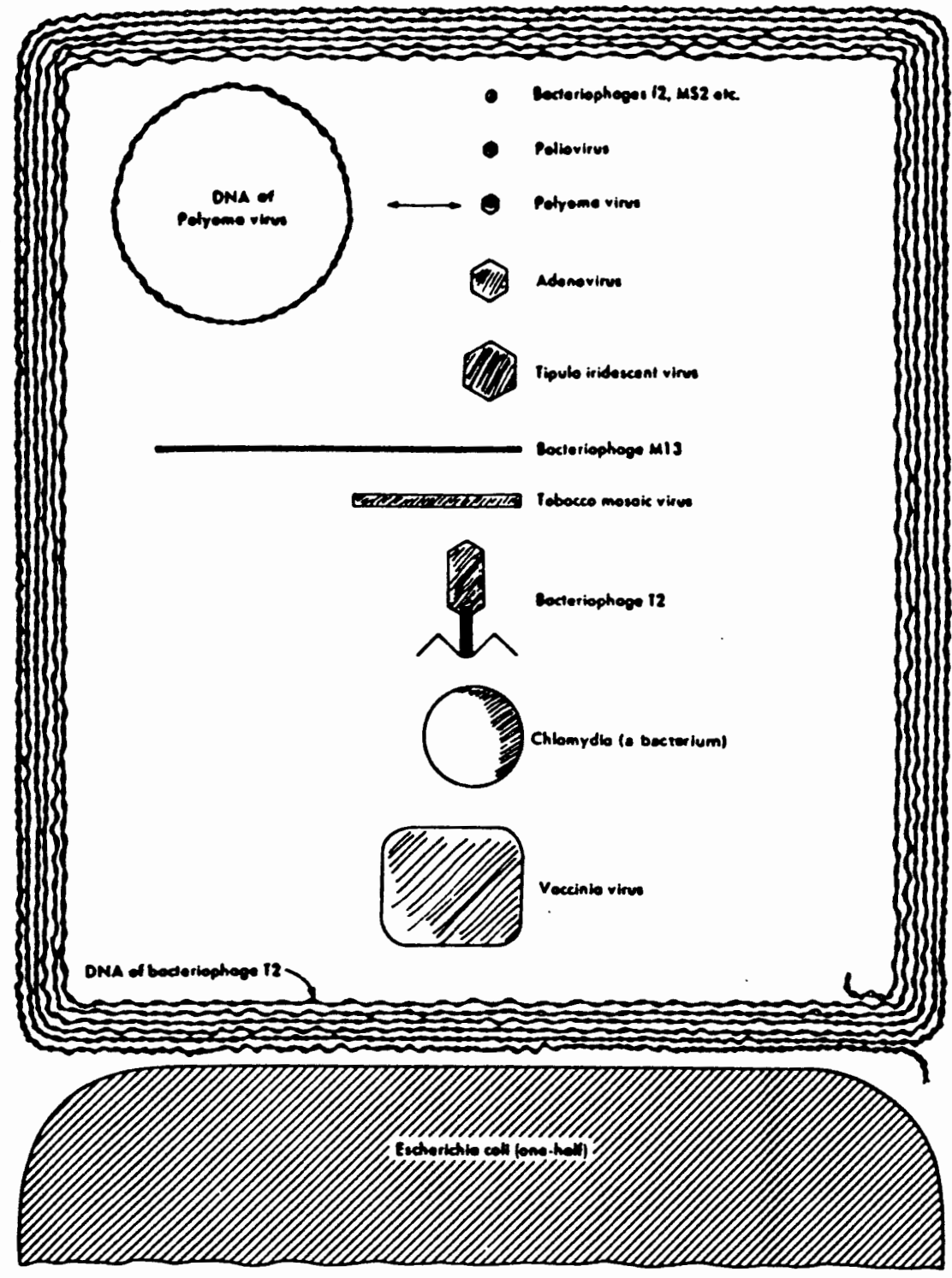

Fig. 1. Comparative sizes of virions, their nucleic acids, and bacteria. The profiles and the lengths of the DNA molecules are all reproduced on the same scale. (Dulbecco. 1988. ) 
The herpesviruses are a very big family named for those members responsible for two common diseases of human: herpes simplex virus (fever blister) and herpes zoster virus (chickenpox and shingles ). The herpesviruses have another characteristic, the ability to produce latent and recurrent infections. Even though the mechanism involved is not very clear, this aspect of herpes infection is very important in both clinical and basic science. Beside human infections, herpesviruses infections have also been found in other species, for example, B virus of monkeys (which may infect man accidentally), pseudorabies virus of pigs, virus III of rabbits, cytomegaloviruses of animals, and oncogenic viruses that produce lymphoproliferative malignancies in chickens and monkeys (49).

\section{The family of human herpesvirus}

The herpesvirus family has almost 100 members that have been at least partially characterized. Among them, seven herpesviruses have been isolated so far from humans. They are: herpes simplex virus type 1 (HSV1), herpes simplex virus type 2 (HSV2), humancytomegalo virus (HCMV), varicella-zoster virus (VZV), Epstein-Barr virus (EBV), human herpesvirus 6 (HHV6), and human herpesvirus 7 (HHV7). All of the human herpes viruses have the same basic architecture which includes four main parts: (a) the core comprised of DNA with some proteins, (b) the viral capsid which is about $100 \mu \mathrm{m}$ in diameter and comprised of 162 capsomeres, (c) the tegument, the structure located between capsid protein and envelope, and (d) the envelope derived from the cells inner nuclear membrane with inserted viral glycoproteins (Fig.2) (11).

Herpesvirus DNAs are double-stranded and linear in nature. Once the virus 


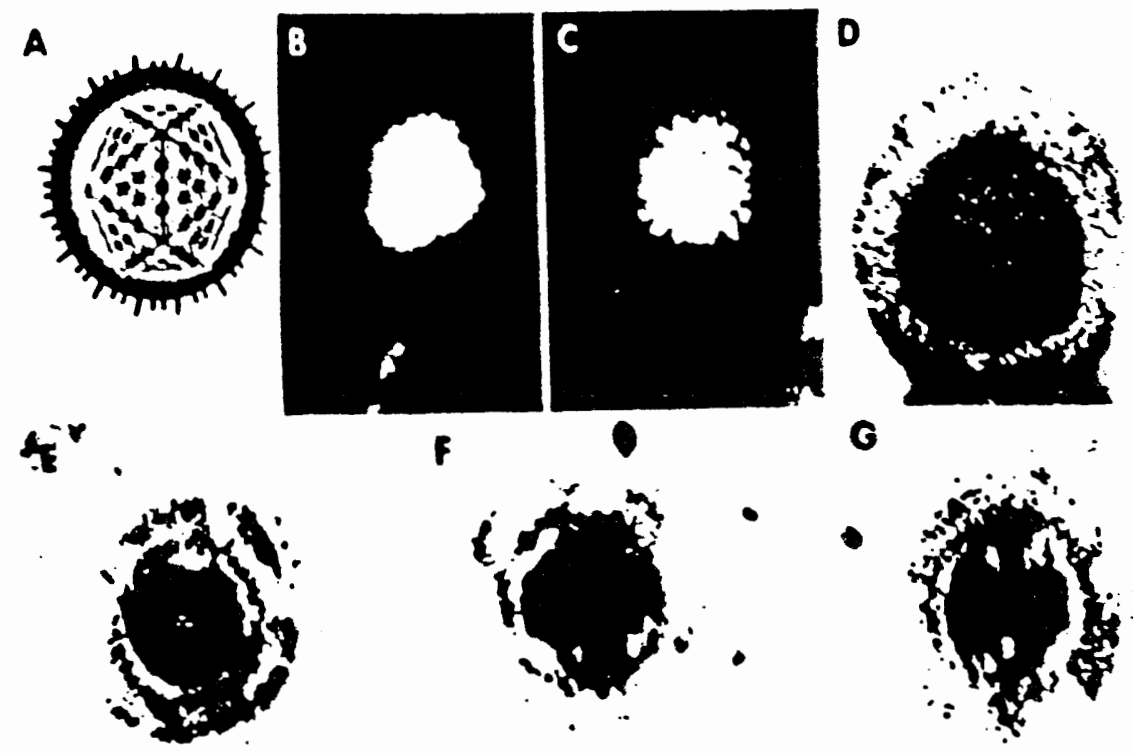

Fig. 2 The morphology of herpesviruses. A: Schematic representation of the herpesvirion seen through a cross-section of the envelope with spikes projecting from this surface. B: An intact negatively stained HSV1 virion. C: An HSV1 capsid in A. D: HSV1 capsid containing DNA permeated with uranyl acetate. E, F, G: Electron micrographs of thin section of HSV1 virions showing the core cut at different angles (Roizman 1993). 
infects the cells, linear DNA will become circular after it is released into the infected cell nuclei. The size of herpesvirus DNAs are approximately 120 to 230 Kilobase pairs (kbp), and they range from $31 \%$ to $75 \%$ in $\mathrm{G}+\mathrm{C}$ content. Although the DNAs of different herpesviruses have different gene structure, the DNA at many of them consist of two covalently linked sequences designed long unit (Ul) and short unit (Us), comprising $82 \%$ and $18 \%$ of the genomes pectively (Fig.3). Because of the ability of the Ul and Us to invert relative each other, many of the herpesvirus genomes have at least 2 , some have 4 equimolar isomers (11).

According to the International Committee on the Taxonomy of Viruses, herpesviruses are divided into three subfamilies (48):

Alpha Herpesvirus ( $\alpha$-Herpesvirus). These infect the cell very rapidly, and quickly spread to adjacent cells in culture. They usually destroy host cells quickly and establish latent infections in neurons. This subfamily includes HSV1, HSV2 and VZV.

Beta Herpesvirus ( $\beta$-Herpesvirus). These have a long reproductive cycle and slowly spread in culture. After infection, the infected cells become enlarged. This subfamily causes latent infection in secretary glands, lymphoreticular cells, kidneys and other tissues. Human cytomegalovirus (HCMV) belongs to this subfamily.

Gamma Herpesvirus ( $\gamma$-Herpesvirus). All these subfamily members replicate in lymphoblastoid cells, $\mathrm{T}$ or B cells. Some can cause lytic infections in some types of epithelioid and fibroblastic cells. Epstein-Barr virus (EBV) belongs to this group. 

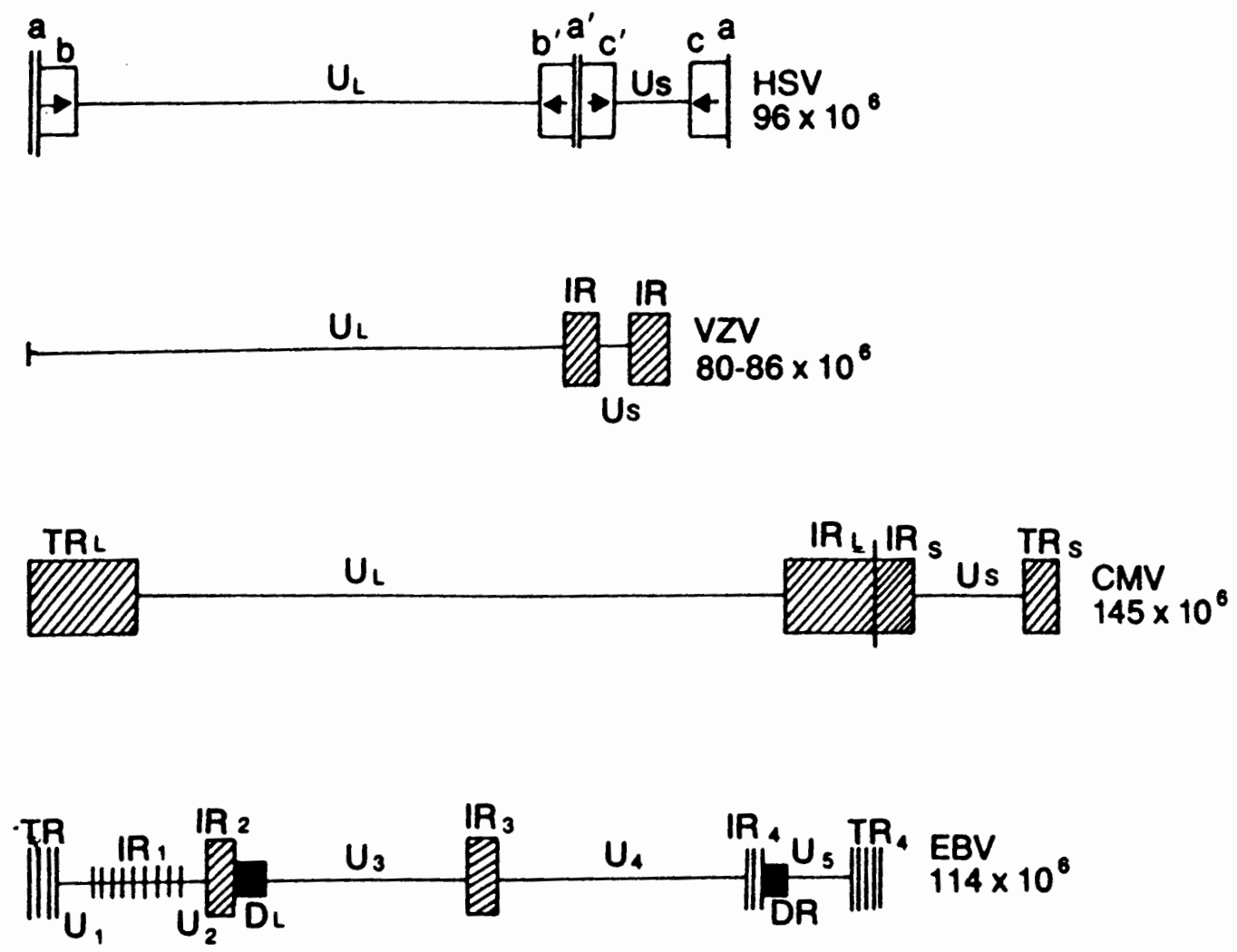

Fig. 3. Diagrams of the physical structures of genomes of several viruses of the family Herpesviridae. The genomes are composed of unique (U) sequences with short (S) or long (L) region. Terminal repeats (TR) bound the genome, and inverted repeats (IR) bound $t$ he unique regions. The rectangles contain reiterated sequences of more than 1000 base pairs. (Dulbecco.1988.) 
As one of the big families of viruses, herpesviruses can cause many diseases in human and other animals. Human herpesviruses are clinically very important for human beings. The most common diseases resulting from herpesvirus infections are chickenpox and fever blisters. Over $87 \%$ of America people been infected by one or more herpesviruses ( 49).

Fever blisters or cold sores are a very common disease resulting from HSV1 infection, the very common area is oral. HSV2 mainly produces genital infections. Only seroepidemiologic studies can distinguish the differences between HSV1 and HSV2. But, usually, the antibodies directed to HSV2 can be tested in the young baby and the antibodies directed to HSV1 can be tested in children less than 10 years old. Skin and mucosal surface are the initial or primary infection sites for HSV1 with the mouth and lips being the most common places of the infection of HSV1. Manifestations of the infection can be fever, sore throat, ulcerative and vesicular lesions, edema and so on. The incubation period ranges from 2 to 12 days. And the duration of clinical illness is about 2 to 3 weeks (49).

The most common diseases caused from the VZV are chickenpox (varicella ) and shingles ( herpes zoster ). Chickenpox is a ubiquitous, highly contagious, generalized exanthem that spreads rapidly in a susceptible population and displays marked seasonality. Shingles ( herpes zoster) occurs usually in older individuals and is characterized by a painful vesicular eruption generally limited to a single dermatome.

In the herpesvirus family, the most important thing that is different from other viruses is that herpesviruses can produce both primary and recurrent infections. The recurrent infections are due to the abilities to establish latency. The primary infections occur mainly in children, and the recurrent infections in adults. After a primary HSV infection, the latency can be established very soon in the neurons. This is believed to 
occur without the production of cell death, because the viruses generally do not replicate in the neurons. For example, the reactivation of HSV can be many caused by exposure to cold, sunlight, wind, dental procedures, sexual intercourse.

\section{Herpes simplex viruses and their life circle}

This research focuses on herpes simplex virus type 1 (HSV1). This virus causes many different kinds infections in humans. The most common disease caused by HSV1 are fever blisters or cold sores as described before. The more severe manifestations of HSV 1 infections are: (a) disseminated disease to visceral organs, (b) the severe deep ocular involvement which can lead to blindness, and (c) herpes encephalitis (49). A unique property of the herpes simplex viruses is their ability to cause latent infection in neurons. Normally, after first infection, they travel to the sensory neurons that innervate the region of infection. There they can remain latent in their host and they can be later reactived to cause lesions at or near the site of initial infection. Latent virus has been retrieved from the trigeminal, sacral and vagal ganglia of humans (49). Reinfection with the same strain of HSV can occur by autoinoculation at a distant site. So, the HSV1 can be mechanically transmitted from one site to either an adjacent site or a distal site $(11,48,49)$.

The replication cycle of HSV1 has been extensively studied, and it is comprised of the following steps (Fig.4) $(11,24,48)$ :

(1). Attachment: All the susceptible cell membranes have the HSV1 receptors to match the antireceptors on the virus surface. When the virus has attached to the cell surface, the viral envelope fuses with the cell membrane and the nucleocapsid is released 
into the cytoplasm. This step does not need any energy which depends on the specific affinity between both cell and virus glycoproteins B, D, H, K, L. Normally, herpes simplex viruses infect and replicate in epithelial cells and become latent in neuron cells.

(2). Penetration: Herpesviruses penetrate the infected cell by fusion of the viral envelope and cell plasma membrane. This step rapidly follows attachment . Viral glycoproteins $\mathrm{E}(\mathrm{gE}), \mathrm{gB}$ and $\mathrm{gD}$ perform very important functions in this procedure.

(3). Uncoating: After entering the cell, the viral capsid is transported to the nuclear pores quickly and then the DNA is released into the nucleus.

(4). Replication. DNA replication, transcription and new capsid assembly occur in nucleus. Herpes simplex viruses have 72 gene products, 56 open read frames are in Ul, 12 in Us and 1 each in the repeat regions (Fig.3). All of the viral genes and their products are divided to 5 groups: $\alpha, \beta 1, \beta 2, \gamma 1$ and $\gamma 2$ based on the kinetics of the ir expression $(24,33,34,47,48,54,60)$.

Immediate-early or $\alpha$ genes are the first expressed following infection. Those include ICP0, ICP4, ICP22, ICP27 and ICP47 (62). These proteins are synthesized 24 hours after infection without the requirement of DNA replication; the $\beta 1$ and $\beta 2$ genes reach their peak of expression after 5-7 hours infection, $\beta 1$ genes include these for viral ribonucleotide reductase and the major DNA binding proteins; examples of $\beta 2$ genes are the viral thymidine kinase (TK) and DNA polymerase. The late or $\gamma$ genes include $\gamma 1$ and $\gamma 2$ depending on their time of initial transcription and the requirement for viral DNA synthesis for their expression $(21,59)$. The $\gamma 1$ genes are expressed somewhat earlier than the $\gamma 2$ class, and their expression shows only a partial dependency on DNA replication. Thus they are first expressed before DNA replication, but they reach their maximal level expression after DNA replication (59). The major capsid protein, VP5 is in the $\gamma 1$ class. 


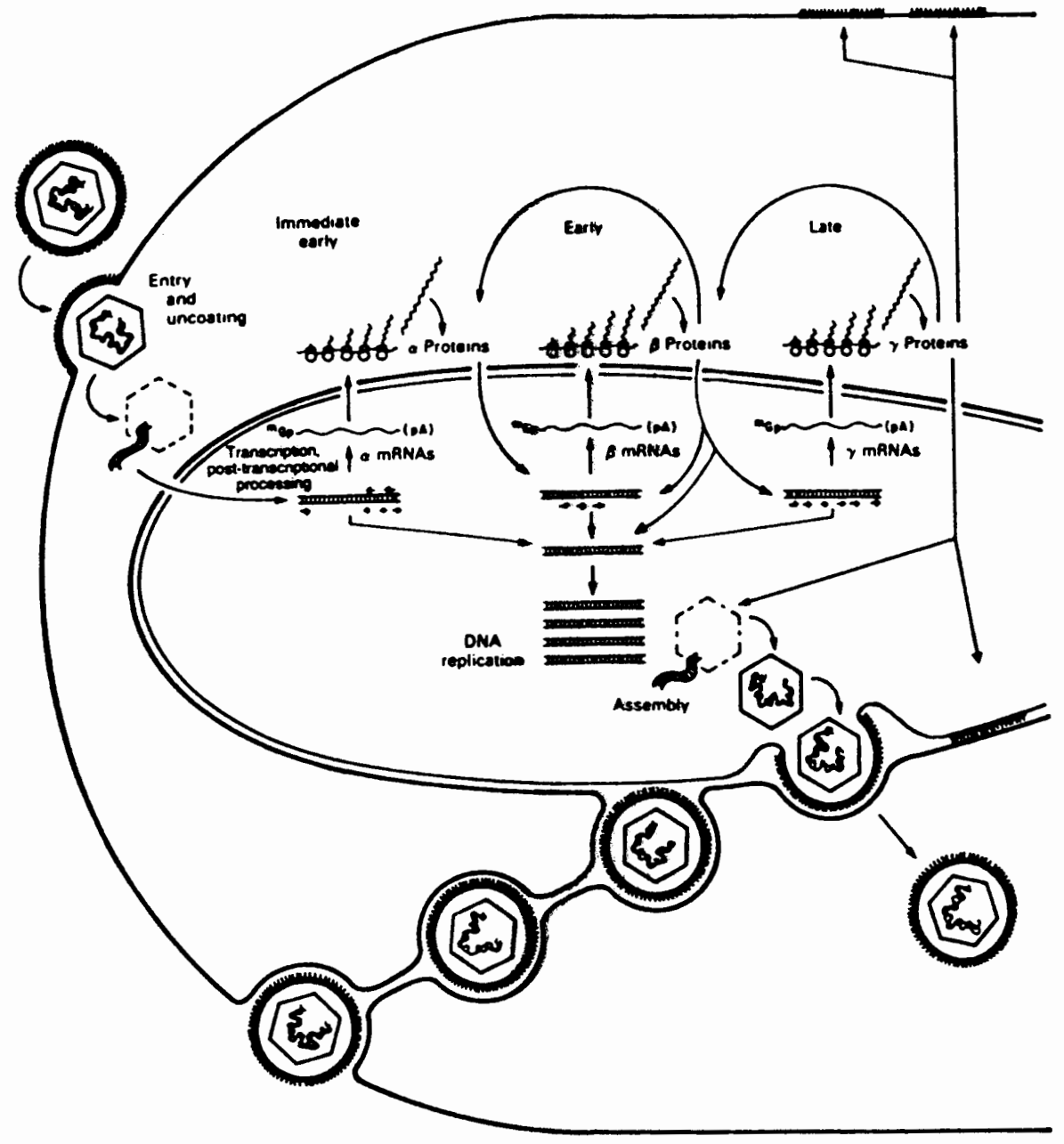

Fig. 4. Sequence of events in the multiplication of herpes simplex virus from entry of the virus into the cell by fusion of the virion envelope with the membrane of the endocytic vacuole to assembly of virions and their exit from the cell through the endoplasmic reticulum (Dulbecco 1988.) 
(5). Translation. Translation of HSV 1 mRNAs occurs in the cytoplasm, on both free and bound polyribosomes. Structural and most regulatory proteins are transported into the nucleus.

(6). Assembly and release. After gene expression, nucleocapsid assembly occurs in the nuclei of host cells. The virus acquires its envelope by budding through inner nuclear membrane that has been modified by insertion of viral glycoproteins from the host nuclear membrane (48).

\section{Viral Gene Regulation}

Generally, as described above, herpes simplex virus 1 (HSV1) gene expression occurs as a cascade in an orderly sequence from $\alpha$ (immediate-early, IE), through $\beta$ (early, or delay-early, DE), and then to $\gamma$ (late, L) gene expression, $(2,7,8,17,20,22$, $23,26,40,61)$. IE genes expression does not require the DNA replication $(11,12$, $41,42)$. Immediate early proteins ICP0 and ICP4 perform very important roles in regulating transcription. Also, IE genes contain numerous other cis-acting sites for CAAT-box binding proteins shown to affect gene expression. After the virus enters host cell, they initiate gene expression immediately. ICP27, on the other hand, works moinly at the post transcription step $(3,6,9,13,14,33,45,50,51,57,58)$. Both the $\beta$ and $\gamma$ gene expression require the function of IE proteins, ICP0 and ICP4 $(3,13,14)$.

Depending on the timing of gene expression and the requirement of DNA replication $\gamma$ gene expression is divided to two subgroups called $\gamma 1$ or "leaky-late" gene that are transcribed and expressed at low levels prior to viral DNA replication, but after DNA replication $\gamma 1$ genes are expressed at higher levels (25), and the $\gamma 2$ genes are expressed 
after DNA replication $(15,22,23,25,26)$.

My Master's research focuses on the gene regulation of the VP5, major capsid protein of the virus which serves as a model for the $\gamma 1$ gene class. VP5 is a $155 \mathrm{kDa}$ polypeptide that forms the hexamers of the viral nucleocapsid $(4,7)$. Exactly how expression of VP5 is regulated is not well understood. Gene expression studies using cycloheximide reversal $(22,62)$ and immediate-early (IE) gene mutants of HSV1(6, 9,17, 32) showed that IE proteins (ICP0, ICP4, ICP27) are required for $\gamma 1$ and VP5 gene expression. Also, workers using DNA synthesis inhibitors have demonstrated that viral DNA replication is necessary for maximum $\gamma 1$ gene expression $(5,21,40)$.

Many laboratories have shown that VP5 promoter is essentially inactive in uninfected cells, but is strongly activated by virus superinfection $(2,4,13,26)$. Also, cotransfection experiments showed that IE genes (ICP0, ICP4, ICP27) are necessary for transactivation of reporter gene fused to $\gamma 1$ promoters $(4,5,13,51)$. However recent evidence indicates that the major effect of ICP27 in such studies is at the posttranscriptional level (57).

Further work in this laboratory has demonstrated that a specific VP5 promoter sequence, GGCCATCTTGAA called leaky-late gene binding site (LBS), is very important during VP5 gene expression (4). Using gel mobility shift assay and footprinting, Chen et al found this LBS is a binding site for cellular protein. Transient expression assays of bacterial CAT (chloramphenicol acetyl transferase) gene coupled to the VP5 promoter showed that this LBS is required for maximum transactivation by superinfection HSV1.

Current work in this laboratory proved that the protein that binds to the LBS is YY 1 or YY1-like protein (36). YY1 is a cellular transcription factor (also known as NF-E1, UCRBP and $\delta$ ), a kind of zinc-finger protein, that has both positive and 
negative regulatory properties depending on the gene context. Also with some genes, YY1 performs as initiator role. So YY1 can function as an activator, a repressor, or an initiator of transcription $(1,19,29,39,46,53,54,55)$. Recently, Lee and Shi et al. found that there is some physical interaction between YY1 and SP1 proteins (52). And Seto, Lewls and Shenk have reported that there are interactions between the YY1 and SP1 proteins during eukaryotic gene expression (53). The new finding in YY1 research is that YY1's function depends on its orientation on the DNA and its ability to bend DNA (37).

Based on the previous work, we know that deletion of 35 base pairs (bp) containing the LBS (YY1 binding site) of VP5 resulted in a transient expression of a CAT report gene that was 7-8 fold reduced (4). However, since this deletion includes more than the YY1 binding site, adjacent sequences may also be involved.

From these results, a number of important questions arose:

1. Are the promoter sequences adjacent to the YY1 binding site involved in VP5 gene regulation?

2. What would be the effect of mutating only the YY1 site and not the adjacent regions? Which base pairs are required for YY1 action and transactivation by HSV1?

3. How dose YY1 binding influence VP5 transcription and how does it interact with viral genes, for example IE $(\alpha)$ regulatory proteins?

These are some of the questions I proposed to address in my thesis research. In order to solve these problems, I designed my master research as two parts: Project 1 and Project 2. In project 1 , I concentrated on an investigation of YY1 function in VP5 transcription by subcloning the VP5 promoter, and in the project 2, I designed more detailed point mutations in the YY1 binding site to study YY1's function. 


\section{CHAPTER II}

\section{THE PURPOSE OF THE RESEARCH IN THIS THESIS}

It has been shown that the leaky-late gene binding site ( LBS, called YY1 binding site now ) within the promoter of VP5 is very important for regulation of gene expression (4). This site ( GGCCATCTTGAA ), located at -64 to -75 , was recently found to be bound by a cellular transcription factor YY1 ( 36 ). The evidence for regulation of VP5 promoter activity by YY1 is as follows: First, deletion of 35-base pairs containing the LBS fragment from the VP5 promoter resulted in a7-8 fold reduction in gene expression from a bacterial CAT (chloramphenicol acetyl transferase) reporter gene following HSV1 superinfection. In similar experiments, deletion of half of the LBS resulted in 3-4 fold reduction of the CAT gene expression . Secondly, gel mobility shift assays showed that LBS can form two complexes with a host cell nuclear extract. Gel mobility shift competition assays indicated that the protein forming both complexes (A and B) with LBS was related to the YY1 protein, or YY 1 forms the complex A; probably a proteolytic product of YY 1 forms complex B. Thirdly, protein binding to the full length VP5 promoter labeled fragment was effectively competed away with excess amounts of LBS, YY1 and CF1 oligonucleotide, while a nonspecific oligonucleotide, C2 lacking a YY1 site had no effect. So the LBS is the specific binding site for the YY1 protein. Moreover, partial proteolysis assays of LBF and YY1 
complexes further identified LBF ( leaky-late gene binding factor) as the transcription YY1.

Based on the above results, I was trying to answer the following major questions in my master research project:

1. What is the function of YY1 in the capsid protein VP5 gene expression?

In the previous studies, deletion of 35 base pairs (bp ) region containing the LBS, or YY1 binding site (called del. \#13) reduced the reporter gene expression 7-8 fold. Since this $35 \mathrm{bp}$ region contains sequences other than the LBS site, I proposed to create a reporter lacking only the consensces LBS sequence. On the other hand, if the LBS does play a role in regulation of VP5 transcription, insertion of the LBS back into the mutated plasmid without LBS should restore promoter activation. Therefore, I would also create this reporter.

2. In the YY1 binding site, which base pairs are required for YY1 function?

3. Assuming YY1 is the major cellular protein binding the LBS site and forming the DNA-protein complexes, does it interact with other cellular or viral transcription factors? If so, how does it interact with them to regulate transcription? To answer these questions, I designed my master research as two projects:

Project 1: To create new mutations within the YY1 binding site of the VP5 wild type promoter ( wt VP 5) and compare their activities with wt VP5 .

Based on the previous work, using the same VP5(-168) CAT plasmid as wild type (wt) VP5 and previous constructed promoter mutations, \#13 and \#6 (Fig.5), I made two further VP5 constructs. One is a 22 base pair deletion in which LBS (YY1 binding site ) was deleted, called 13/6. The other one is an insertion of an 
oligonucleotide including the VP 5 LBS sequence back into the mutated 13/6; this was called LBS/13/6. I then carried out three major types of experiments to measure the function of the mutated promoters as compared to the wt VP5:

A. To determine if the newly constructed VP5 promoter mutations were able to bind YY1 or not, I carried out gel mobility shift assays using labeled promoter fragments and HeLa cell nuclear extracts. These experiments would establish DNAprotein complexes were being formed. The mechanism of a gel mobility shift assay is based on the fact that binding of a protein to a DNA sequence increase the molecular weight of the DNA probe resulting in a retardation of its mobility through a gel.

B. To measure the function of the mutated promoters, I carried out transient expression assays in human HeLa cells. In these assays, promoter activity was analyzed by its ability to drive expression of linked reporter gene. For this purpose, I used bacterial chloramphenicol acetyl transferase (CAT) positioned downstream of wt and mutated VP5 promoters. Transfection of these plasmids into HeLa cells leads to production of the CAT protein following promoter activation (see chapter III) The final product acetyl-CAM was dissolved in benzene. After evaporation of the benzene, a radioactive buffer solution was added, then the Acetyl-CAM was counted by radioactive counter automatically. This assay allows us to analyze the wt and mutated VP5 promoter activities.

C. To identify the DNA-protein complexes formed by YY1, I used competition gel mobility shift assays. First, a Hela nuclear extract (containing endogenous YY1) was allowed to bind to a labeled VP5 promoter fragment. Then an excess amount of unlabeled DNA fragment is added into the reaction tube. If the unlabeled DNA fragment contains a suspected protein binding site, it will bind the nuclear extract protein quickly, and we will see a reduced binding of the protein to the labeled DNA probe. In these 
experiments, the ability of specific unlabeled oligonucleotides were tested for their ability to inhibit complex formation.

Project 2. To make point mutations on LBS of wt VP5 and compare their function to wt VP5.

Even if I can get more information about LBS function in VP5 gene expression from project 1, I still think that it is just very general information. For a more detailed analysis, I should make point mutations within the LBS sequence to see which base pairs are performing the key role in regulation of VP5 gene expression. So, I designed two point mutations in LBS. I have mutated the wild-type LBS (GGCCATCTTGAA) to either ATCTATCTTGAA or GGCCAGATCTAA ( mutations underlined). Both the mutations have a new $B g l$ II site (wt VP5 dose not have BglII cut point.) making further work very convenient.

To construct these mutations, I used PCR (polymerase chain reaction) with mutant oligonucleotide primers. On my wt VP5 promoter, one end has the Sal I cut point, the other end has Hind III site. For each point mutation, I designed the Sal I (sense)/Bgl II ( anti-sense) and Bgl II(sense)/Hind III ( anti-sense) primers. Then I used the PCR technique to amplify the mutated region and ligated this into wt VP5 big fragment cut by Sal I and Hind III ( the detailed information is in the chapter III). Mutation 1 and mutation 2 have only a few base pairs different from the wt VP5 promoter. All the rest parts of the plasmids are exactly same as wt VP 5 plasmid. In the project 2, I would use gel mobility shift assay, CAT assay and competition gel mobility shift assays to test the functions of the point mutations in VP5 promoter. 


\section{CHAPTER III}

\section{MATERIALS and METHODS}

\section{Materials}

\section{Plasmids}

Plasmid pVP5 (-168) CAT contains the wild-type (wt) herpes simplex virus 1 (HSV1) capsid protein (VP5) promoter sequence from -168 to -4 base pairs (bp) from the cap site linked to the bacterial chloramphenicol acetyl transferase (CAT) gene. pVP5(-168) CAT was provided by E. Blair and E. Wagner, University of California, Irvine, CA. Plasmids VP5 \#6 and \#13 were created from pVP5 (-168) CAT in this laboratory as described previously (4) (Fig.5). VP5 \#6 contains a 12 base pairs Bgl II linker inserted between -80 and -81 bp. of pVP5 (-168) CAT. VP5 \#13 (also called deletion \#13) (4) contains a deletion of 35 base pairs from -59 to -93 including the leaky-late gene binding site (LBS). Further specific deletions or mutations in the wildtype VP5 (wt VP5) promoters were produced from above plasmids as described below. All plasmid DNAs were prepared in one of the two ways: (1) By the alkaline lysis method (31) as modified by this laboratory (4) and further purified by $\mathrm{CsCl}$ buoyant density centrifugation to isolate supercoiled DNA for transfections. (2) By the use of Qiagen 500 tips (purchased from Qiagen company) to isolate supercoiled forms following described by the manufacture.

\section{Oligonucleotides}


TABLE 1 Oligonucleotides

\begin{tabular}{lll} 
Name & Source of Sequence & Sequence \\
\hline LBS & $\begin{array}{l}\text { LBF binding site } \\
\text { of HSV-1 VP5 }\end{array}$ & 5 CCAGGATCCAGGGCCATCTTGAATGGATCCTGG \\
CF1 & $\begin{array}{l}\text { CF1 binding fite of } \\
\text { murine c-myc promoter }\end{array}$ & 5' GGGCGCGAGAAGAGAAAATGGTCGGGC \\
YY1 & $\begin{array}{c}\text { YY1 binding site of P5 } \\
\text { of adeno-associated virus }\end{array}$ & 5, GATCTCCATGGTTTTGCGACATTTTGCGACA \\
C2 & $\mu$ E3 binding site of murine & 5' CCTTGCCATGACCTGCTTCCT
\end{tabular}

TABLE 2 PCR primers

\begin{tabular}{lll}
\hline Name & Location & Sequence \\
\hline Sall & Mut.1 and 2 & CTGGGTTGAAGGCTCTCAAGGGC \\
HandIII & Mut.1 and 2 & CTTAGCTCCTGAAAATCTC \\
Mut.1 a & Mut. 1 & GCATTCAAGATAGATCTGGTCCAAAAGC \\
Mut.1 b & Mut. 1 & CTTTTGGACCAGATCTATCTTGAATGCACC \\
Mut.2 a & Mut. 2 & CGGGTGCATTAGATCTGGCCCTGGTC \\
Mut.2 b & Mut. 2 & ACCAGGGCCAGATCTAATGCACCCGTC \\
\hline
\end{tabular}


A. The following double-stranded oligonucleotides were used as unlabeled competitors in gel mobility shift assays (Table 1): (1) LBS, contains the binding site for the leaky-late gene binding factor (LBS or YY1 binding site) from the VP5 promoter with BamH I sites at each end was synthesized by the vollum institute, Oregon Health Science University (OHSU). It is composed of 33 base pair with the following sequences: CCAGGATCCA GGGCCATCTT GAATGGATCC TGG; (2) CF1, contains the binding site for the murine transcription factor called common factor 1 (CF1) from the murine c-myc gene, a gift from K. Riggs and Calame Columbia university. It has 27 base pair with the following sequence GGGCGCGAGA AGAGAAAATG GTCGGGC; (3) YY1 7/8 consists of a $31 \mathrm{bp}$ fragment as: GATCTCCATG GTTTTGCGAC ATTTTGCGAC A. It was provided by E. Seto and T. shenk; (4) SP1 (purchased from Promega. The sequence was not showed); (5) C2 containing the binding site for the murine IgH intronic enhancer the sequence is: CCTTGCCATG ACCTGCTTCT.

B. Oligonucleotide used as single-stranded primers in the polymerase chain reaction (PCR) mutagenesis are shown in Table 2. They were synthesised by the oligonucleotide facility, department of biochemistry (OHSU). (1) Distal primers: Sal I and Hind III as the distal primers, their sequences are: CTGGGTTGAA GGCTCTCAAG GGC and CTTAGCTCCT GAAAATCTC the Hind III primer primes for the antisense strand of the mutated fragment. (2) Mutation 1 sequences: To mutate the LBS, two new sequences including $B g l$ II restriction site were designed, mutation 1 a is: GCATTCAAGA TAGATCTGGT CCAAAAGC and primes the direction to the Sal I primer, and mutation $1 \mathrm{~b}$ is: CTTTTGGACC AGATCTATCT TGAATGCACC to the Hind III direction. (3) Mutation 2 sequences: Mutation 2 a is: CGGGTGCATT AGATCTGGCC CTGGTC priming the direction to the $\mathrm{Sal}$ I primer and mutation $2 \mathrm{~b}$ is: 
ACCAGGGCCA GATCTAATGC ACCCGTC priming to the Hind III primer.

All the primers used in point mutations were synthesised by OHSU described before.

\section{Cells and virus}

HeLa cells (ATCC, CCL2,purchased form GIBCO) (4) were grown at $37^{\circ} \mathrm{C}$ with $5 \% \mathrm{CO}_{2}$ atmosphere in Dulbecco's modified Eagle medium (DMEM) containing $10 \%$ heat-inactivated calf serum (Hyclone Labs, Inc), penicillin $(100 \mathrm{U} / \mathrm{ml})$, and streptomycin $(100 \mathrm{ug} / \mathrm{ml})$. The $v h s-1$ mutant of HSV1 (KOS), defective in a virionassociated host shut off function which located in the UL41 gene $(5,43)$, was provided by G.S. Read, Loyola University of Chicago.

\section{Nuclear Extracts}

Nuclear extracts (NE) prepared by the following method of Dignam $(4,36)$ from either uninfected (mock-infected) HeLa cells or cells infected for 8 hrs. by HSV1(KOS) at a multiplicity of infection of $10-15$ protein concentration of extracts were determined by the lowery method $(36,43)$. NE was diluted to $1 \mathrm{ug} / \mathrm{ul}$ for use in gel mobility shift assays.

\section{Radioactive products}

32P-ATP and ${ }^{32} \mathrm{P}-\mathrm{CTP}$ were purchased from NEN. company, ${ }^{3} \mathrm{H}-\mathrm{Acetyl}$ from OHSU.

\section{Enzymes}

Restriction endonucleases were from Bethesda Research Labs., Inc. (BRL) and 
New England Biolabs (NEB) packaged with the reaction buffer. (KGB was also used a rotine reaction buffer) (31). Bacterial chloramphenicol acetyl-transferase (CAT), Sacetyl coenzyme A synthetase, and coenzyme A were purchased from Sigma Chem. Co. Klenow fragment of DNA polymerase, T4 DNA ligase, RNase were from BRL. Taq polymerase and $\mathrm{MgCl}_{2}$ buffer were purchased from OHSU. Calf intestinal phosphatase (CIP) was purchased from Sigma company. Sequenase enzyme, buffers, and dideoxynucleotides for sequencing were purchased as the Sequenase 2 kit from U.S. Biochemical Company.

\section{Methods}

\section{Construction of Subcloned VP5 Promoter Mutations.}

A. Deletion 13/6. Plasmids \#13 ( without LBS, including Bgl II linker ) and \#6 described before, 100ug for each one, were cut by enzymes $N c o$ I and $B g l$ II (3-4U/ul), and incubated at the $37^{\circ} \mathrm{C}$ for $2 \mathrm{hrs}$. Then added $1 / 10$ volume of the $10 \mathrm{X}$ stop dye, loaded and ran samples on 1\% agaros gel 600-800 volts hr. 4 binds were obtained ( both $N c o$ I and Hand III have one cut site ), 2 big ones (about $3.1 \mathrm{~Kb}$.) and 2 small ones (about $0.6 \mathrm{~Kb}$.). DEAE paper was used to isolate the DNA fragments from the agorase gel, and higher concentrated salt solution was used for eluting by $1 \mathrm{M} \mathrm{NaCl}$. Finally, the DNA was dissolved in TE ( $10 \mathrm{mM}$ Tris-Cl, 1mM EDTA). The large piece of \#13 and the small piece of \#6 were ligated by using T4 ligase, with incubation at $16^{\circ} \mathrm{C}$ overnight. The ligated plasmid called 13/6 was transformed into bacteria E. coli HB101. The plasmid DNA was prepared as described earlier.

B. LBS/13/6. Oligonucleotide LBS is a 33 base pair double-stranded DNA (Table 


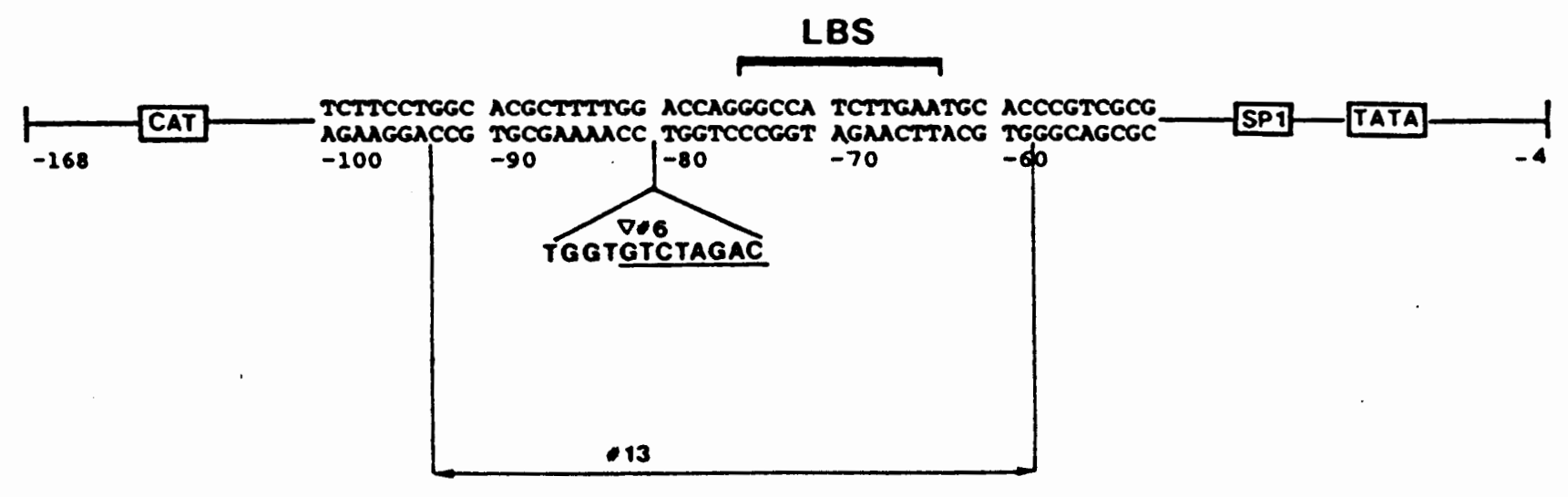

Fig. 5. Mapping of deletion and insertion constructs in the VP5 promoter. The insertion of \#6 is just the original VP5 plasmid plus the BgI II linker, the \#13 deletion of 35 base pairs plus Bgl II linker. (Chen. 1992.) 
Part of promotor

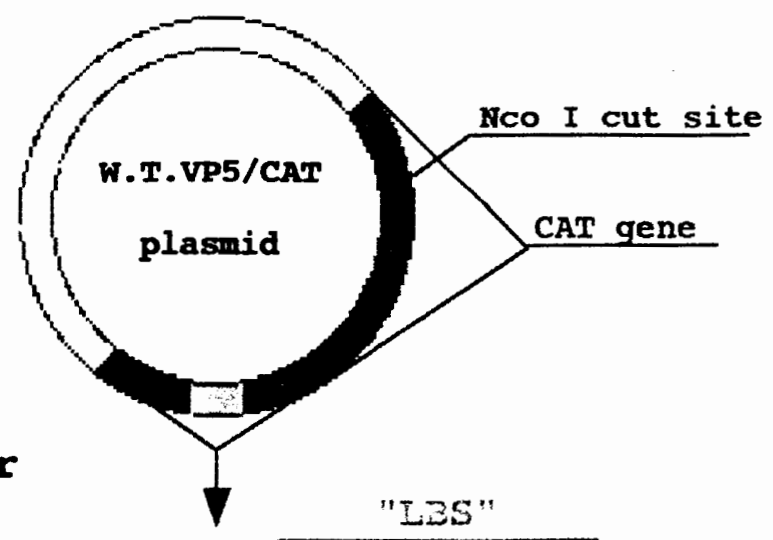

W.T. TCTTCCTGGC ACGCTTTTGG ACCAG NCCA TCTMGIZITC ACCCGTC

AGAAGGACCG TGCGAAAACC TGGTC OCGGI AGAICAMACG TGGGCAG $-100$

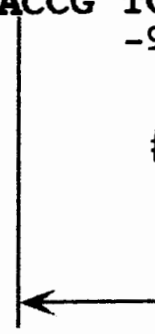

\#6 $-90$

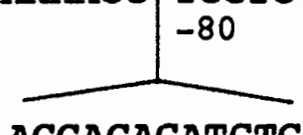

\#6 ACCACAGATCTG TTGTGTCTAGAC

Bgl II Linker

\section{$\# 13$}

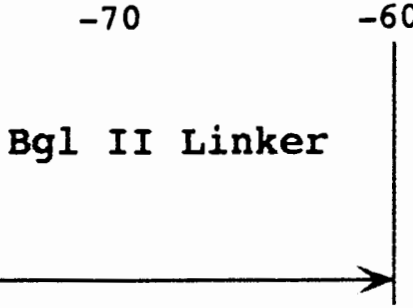

Mutation

desired $=\$ 13 / \# 6$

TCTTCCTGGC ACGCTTTTG ACCACAGATCTG ACCAG AGAAGGACCG TGCGAAACC TTGTGTCTAGAC TGGTC $\mathrm{CGGT}$ AGAACATACG TGGG

$\# 13$

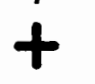

$\# 13 / \# 6$

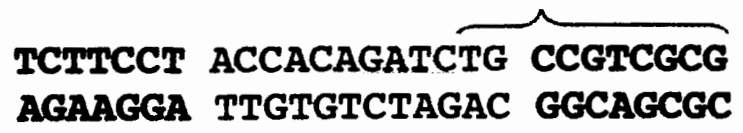

$\downarrow$ Ligate Bgl II to NCO I

TCTTCCTGGC ACGCTTTTGG ACCACAGATCTG CCGTCGCG

AGAAGGACCG TGCGAAAACC TTGTGTCTAGAC GGCAGCGC

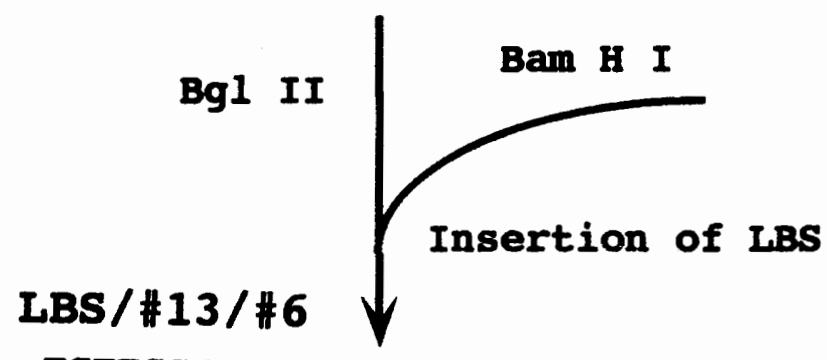

TCTTCCTGGC ACGCTTTTGG ACCACAGATC

AGAAGGACCG TGCGAAAACC TTGTGTCTAG $\frac{\text { "LaS" }}{\text { GGCCATCTMGA }}$ CCOCrnganemt

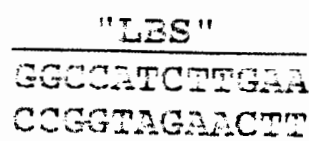

TG CCGT

AC GGCA

Fig.6 Construction of subcloned mutations $\# 13 / \# 6$ and LBS/\#13/\#6 
(Table1) which includes GGCCATCTTGAA (the YY1 binding site). There are two BamHI sites at the both ends of the YY1 binding site. Then $13 / 6$ was restricted by BglII and the LBS oligonucleotide by BamHI as by the usual protocol described before and ligated together to get the plasmid LBS/13/6 (Fig. 6).

\section{Construction of point mutations in wild type VP5 promoter}

In the project 2 , two site-directed mutations were designed. The techniques used were the same for each one.

PCR primers for the SalI and HindIII sites of the wt VP5 promoter were designed (Table 2). Hind III primes for the antisense strand, while Sall primes for the sense strand. Two $B g l$ II primers in each point mutation were designed, one was directed to the SalI site and the other one was directed to the Hind III. Each Bgl II primer contains the mutated sequence (Table 2). BgII mutation 1 a and mutation $2 a$ were directed to the Sal I site, mutation $1 \mathrm{~b}$ and mutation $2 \mathrm{~b}$ were directed to the Hind III. PCR reactions were as follows: The original wt VP5 plasmid served as a template using the DNA primer combinations listed below. Each reaction contained $25 \mathrm{mM}$ magnesium, $2 \mathrm{mM}$ dNTPs and Taq polymerase $0.5 \mathrm{U}$ in a reaction volume of $100 \mathrm{ul}$. Primer SalI was added with primer BglII 1a or 2a, while primer HindIII was added with primer $B g l \mathrm{II} 1 \mathrm{~b}$ or $2 \mathrm{~b}$. Three temperature programs for the thermal cycler (Perkins-Cetus) were used for obtaining PCR fragments: (1) denaturing cycle: $95^{\circ} \mathrm{C}$ for three minutes followed by $45^{\circ} \mathrm{C}$ for 30 seconds, (2) amplification step: 21 cycles, each comprised of 45 seconds at $94^{\circ} \mathrm{C}, 30$ seconds at $42^{\circ} \mathrm{C}$, then $72^{\circ} \mathrm{C}$ for two minutes, (3) elongation step: $72^{\circ} \mathrm{C}$ for four minutes.

The PCR fragments were trimmed by Sall and BglII or BglII and HindIII digestion. Plasmid VP5 \#6 was digested with HindIII and Sall, the large fragment was 
isolated as described before. This piece plus either mutation $1 \mathrm{a}$ and $1 \mathrm{~b}$ fragments from PCR or mutation $2 \mathrm{a}$ and $2 \mathrm{~b}$ fragments from PCR were ligated together as described under subcloning methods.

\section{DNA sequencing}

DNA sequencing was carried out using the dideoxynucleotide chain termination method (Termination reaction method) with the Sequenase 2 kit from US Biochemical Co (USB). The following protocol from USB was used:

Plasmid DNA (3ug) was added to 20ul 0.1 NaOH/0.2mM EDTA and incubated at room temperature for five minutes. The DNA was neutralized by adding 2 ul of $10 \mathrm{M}$ ammonium acetate, precipitated by adding $60 \mathrm{ul}$ ethanol, chilling on ice for 15 minutes, and spun for 20 minutes at $1500 \mathrm{rpm}$ at $4^{\circ} \mathrm{C}$. To precipitate the DNA pellet was rinsed with $70 \%$ ethanol and then dissolved in $7 \mathrm{ul}$ water. To anneal the Sall primer (from USB) to the denatured DNA template the plasmids and the primer were heated at $65^{\circ} \mathrm{C}$ for two minutes in sequencing reaction buffer, and then allowed to cool to below $35^{\circ} \mathrm{C}$. For labeling, the following kit reagents were added to the cooled annealing mixture: DTT (1ul), dGTP labeling mixture (2ul), and 8-fold diluted Sequenase enzyme (2ul). One half microliter ${ }^{32} \mathrm{P}$ dATP or dCTP (NEN) was added as the radionucleotide label. This mixture was incubated at room temperature for 2.5 minutes.

For each sample to be sequenced four termination mixture tubes were prepared containing 2.5ul of dideoxynucleotide termination mixtures (of ddGTP, ddATP, ddTTP, or ddCTP) and warmed to $37^{\circ} \mathrm{C}$. Aliquots of the labeling reaction (3.5ul) were added to each termination mixture for that sample and incubated at $37^{\circ} \mathrm{C}$ for five minutes. To stop the reaction, 4 ul of stop solution were added to each reaction tube.

To determine the sample DNA sequence, $3.5 \mathrm{ul}$ from each of the samples 
reaction tubes were loaded onto a $6 \%$ polyacrylamide sequencing gel (prepared using USB protocal). Gels were electrophoresed at 1,700 volts, 35-45 watts, for 2 hrs. 3MM paper was used to support the gels during vaccuum drying. The gel was exposed to Fuji RX film for 8 hours with an intensifying screen at $-75^{\circ} \mathrm{C}$ and then developed by atandard procedures.

\section{Gel shift mobility assays}

SalI/HindIII fragments were used in the gel mobility shift assays from: wt VP5 and VP5 promoter mutants, 13/6, LBS/13/6, and point mutations 1 and 2 . The fragments were isolated on DEAE paper as described previously. The ends of each promoter fragment were filled-in using the Klenow fragment with ${ }^{32} \mathrm{P}$ dCTP was incorporated as the radionucleotide label. For each assay, 0.6 ng of the DNA probe, lug of poly ( $\mathrm{dI}-\mathrm{dC})$ and lug of HeLa nuclear extract were mixed in a reaction buffer providing a final concentration of $6 \mathrm{mM}$ Tris- $\mathrm{HCl}(\mathrm{pH} 7.9), 40 \mathrm{mM} \mathrm{KCl}, 2 \mathrm{mM}$ EDTA, $0.2 \mathrm{mM}$ dithiothreitol, and $8 \%$ (vol./vol.) glycerol in a total volume of $20 \mathrm{ul}$. After incubating at room temperature for 30 minutes, 2 ul of $0.25 \%$ bromophenol blue dye were added. The samples were electrophoresed at $4^{\circ} \mathrm{C}, 250$ volts, through a $4 \%$ polyacrylamide gel in non-recirculating buffer (NRB, also known as DBB2 ) $(31,36)$. The gel was vacuum dried on $3 \mathrm{MM}$ paper and exposed to Fuji RX film at $-70^{\circ} \mathrm{C}$. The film was developed as previously described $(10,16)$.

For the competition assays, the only difference from the basic gel mobility shift assay described above was adding 100-150 times molar excess of various unlabeled oligonucleotides (Table 1) before adding the nuclear extract to the reaction.

\section{Transient gene expression CAT assays}


The calcium phosphate precipitation method was used for transfection $(4,18$, 36). HeLa cells were grown at $37^{\circ} \mathrm{C}$ under $5 \% \mathrm{CO}_{2}$ atmosphere in Dulbecco's modified Eagle medium. (DMEM, from GIBCO Laboratories) containing $10 \%$ heat inactivated calf serum (HyClone Labs, Inc.), streptomycin 100ug/ml, and penicillin $100 \mathrm{units} / \mathrm{ml}$. When the cells were $80-90 \%$ confluent, they were seeded into $35 \mathrm{~mm}$ well cluster dishes at $3 \times 10^{5}$ cells per well in DMEM containing $10 \%$ fetal bovine serum. The medium was changed after 17 hours. After seeded 20 hours, the cells were transfected with various reporter plasmids. The tested plasmids 8ug and pUC18 (without CAT gene ) 8 ug were added to $0.25 \mathrm{ml}$ of $2 \mathrm{X}$ HBS buffer $(4,31,38)$. Then, $0.25 \mathrm{mM} \mathrm{CaCl}_{2}$ $(0.25 \mathrm{ml})$ was added with gentle bubbling. This was incubated at room temperature for 30 minutes. The DNA mixture was applied to the HeLa cells, which were then incubated at $37^{\circ} \mathrm{C}$ for four hours. The cells were glycerol shocked $4-5 \mathrm{hr}$. after transfection for one minute (15\% glycerol in DMEM-10\% inactived fetal serumpenicillin $(100 \mathrm{units} / \mathrm{ml}) / \mathrm{streptomycin}(100 \mathrm{ug} / \mathrm{ml})$. The cells were washed three times with PBS-A (0.14M NaCl, 2.7mM KCl, 4.3mM Na $\left.2 \mathrm{HPO}_{4}, 1.5 \mathrm{mM} \mathrm{KH}_{2} \mathrm{PO}\right)$. Then DMEM containing $10 \%$ fetal serum was added to the cells again and the cells were incubated at $37^{\circ} \mathrm{C}$ in a humidified incubator for 22 hours. The cells were superinfected by HSV1 (vhs-1) in PBS/ $10 \%$ glucose $1 \%$ inactivated calf serium at a multiplicity of infection at 3 and incubated at $37^{\circ} \mathrm{C}$ for one hour. Then the virus was removed from the cells, DMEM with $10 \%$ fetal calf serum was added and they were incubated at $37^{\circ} \mathrm{C}$ before. The cells were harvested 48 hours after transfection (4) (see the chart attached next page).

The cells were washed, lyzed, and assayed following the method of Nordeen, et al. (38). Briefly the CAT assay experiment can be described as the followings: The first step was to get radioactively labeled acetyl-CoA from the labeled ${ }^{3} \mathrm{H}-\mathrm{Na}$-acetate (NEN 
Research Products, Inc., $3.3 \mathrm{Ci} / \mathrm{mmol}, 10 \mathrm{mCi} / \mathrm{ml}$ ) into cetyl-chloramphenicol using the coupled reaction with Acetyl-CoA synthetase. Then one can get the radioactiely labeled Acetyl-Chloranphenical ( Acetyl-CAM) under the function of CAT. And the AcetylCAM can be extracted by benzen. The solvent was then evaporated. Finally AcetylCAM was quantitated by scintillation counting (4). 


\section{CAT assay procedure}

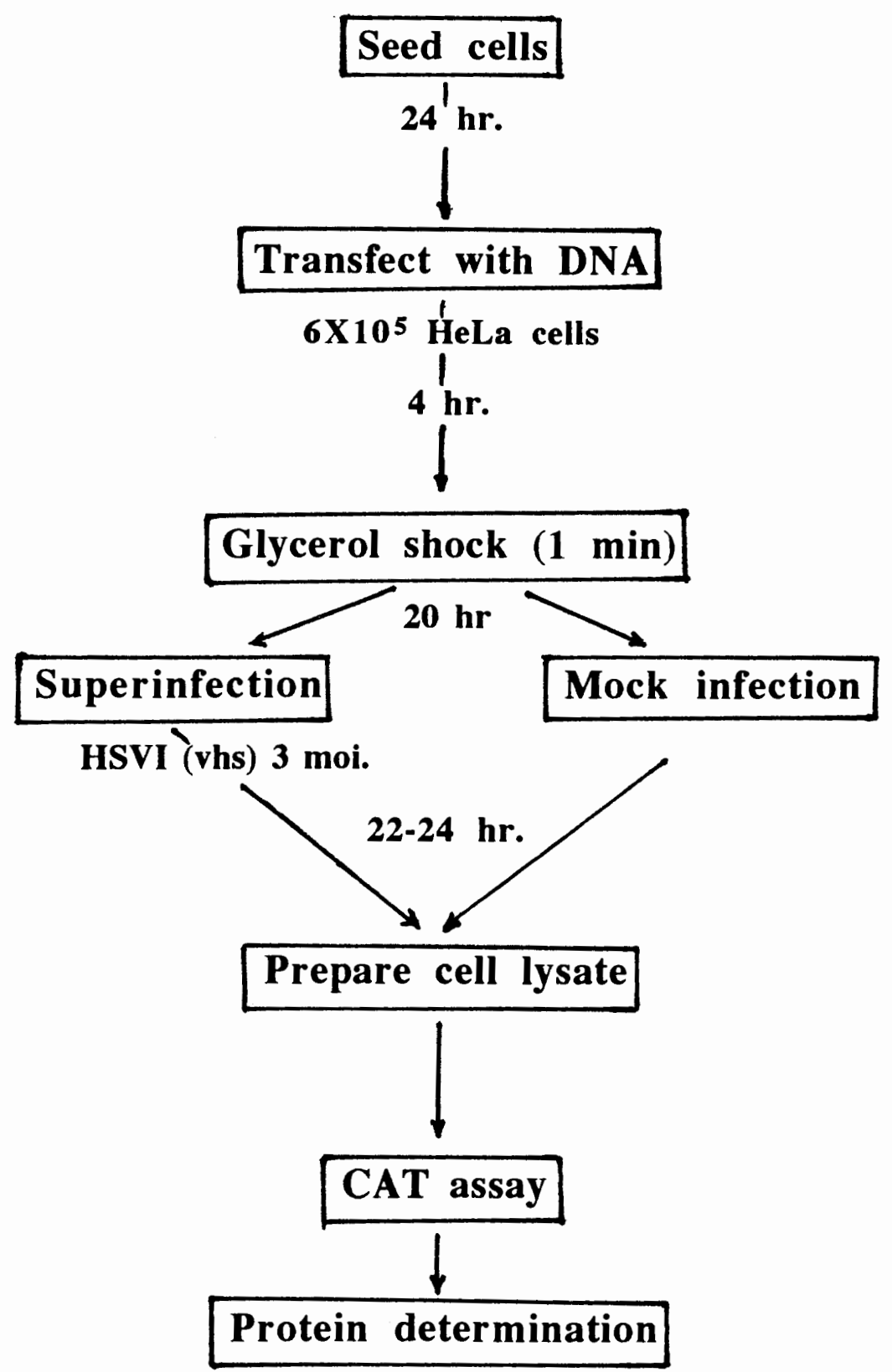




\section{CHAPTER IV}

\section{RESULTS}

According to this laboratory's recent findings ( 4 ), the herpes simplex virus leaky-late gene binding site, (LBS, now called the YY1 binding site ), located between -64 and-75 in the VP5 promoter, is required for maximum transactivation of the VP5 gene (details described in chapter I ). Furthermore, this laboratory identified a new cellular protein factor, the LBF (leaky-late gene binding factor) that binds to this site. (4). And further work in this laboratory (36) has proven that the LBF is identical to the previously described cellular factor called Yin-Yang 1 (YY1, also known as UCRBP, CF1, F-ACT1, NF-E1 ). YY1 has been known performing different functions in different gene expression (56).

From these previous studies, many new questions arose. For the purpose of this thesis, the main questions to be answered are the following:

1. What is the function of the LBF ( YY1) and its binding site in the major capsid protein, VP5, gene expression?

2. How does the YY1 binding site ( LBS ) function in regulating VP5 gene expression?

3. Assuming YY1 is the major cellular factor to bind LBS, what are the interactions between YY1, viral regulatory proteins and cellular transcriptional proteins ?

In order to answer these questions and understand the mechanisms of the LBS 
(leaky-late gene binding site, or YY1 binding site) in the gene regulation of herpes simplex virus 1 (HSV1), two projects were designed in my Master thesis research.

Project 1 focused on the subcloning of mutations in the VP5 promoter and analysis of their functions. In this project I investigated the function of mutated VP5 promoters which either lacked LBS or had the LBS sequence reinserted.

In previous work, S. Chen constructed large deletions in the VP5 promoter that included the YY1 binding site (LBS) (4) (Fig. 5). To construct a smaller, more defined, mutation in the YY1 binding site of the VP5 promoter, I constructed the following mutations: Deletion 13/6: Deletion \#13 that contains the $B g l$ II site without LBS and insertion \#6 that contains the $B g l$ II site were cut by Sal I/Hind III, then the small fragment of deletion \#13 was ligated to the big fragment of insertion of \#6. The new plasmid, called 13/6, has a 22 base pairs deletion that includes the YY1 binding site (LBS ) and the insertion of a 12 base pairs Bgl II linker(Fig. 6). Reinsertion mutation, LBS/13/6: Another important subcloned mutation in project 1 is the reinsertion of oligonucleotide LBS. Deletion $13 / 6$ was cut by $B g l$ II, and oligonucleotide LBS was cut each end with Bam $H$ and then both the above parts were ligated together. Because of the matching part of $B g l$ II and Bam HI site, GATC, the reinsertion of LBS mutation, called LBS/13/6, can not be cut by either $B g l$ II or Bam $H$. So the reinsertion of the LBS mutation could be easily tested by lack of $B g l$ II and Bam HI cutting ( Fig 6)

Project 2 focused on a point mutational analysis of the YY 1 binding site. The purpose of the project 2 was to search for which base pairs have key roles in VP5 gene regulation. In order to observe the function of different regions of the YY 1 binding site, two point mutations, mutation were designed. Mutation 1 changed original YY 1 binding site, GGCCATCTTGAA, to ATCTATCTTGAA, while mutation 2 changed the site to GGCCAGATCTAA. Both the mutation 1 and mutation 2 contain a $B g l$ II site, 
AGATCT, that facilitates later experiments easier. Both mutations were created by using in vitro synthesized oligonucleotides bearing the mutated sequences, PCR, to amplify the mutated regions, and subcloning back into the original plasmid(s).

The main experimental and techniques involved in these projects include plasmid construction, DNA preparation, DNA sequencing, gel mobility shift assay and transient gene expression assay ( see the chapter III ). In this chapter, I will describe the results of Project 1 and Project 2.

\section{Project 1}

As described above, the purpose of Project 1 was to determine the function of the subcloned mutations, deletion $13 / 6$, and the YY1 binding site reinsertion LBS/13/6, as compared to the wild-type (wt) VP5 promoter.

\section{A. Gel mobility shift assays with wild-type and mutant VP5 promoter fragments.}

To verify the removal of LBS in deletion $13 / 6$ and reinsertion in LBS/13/6, gel mobility shift assays were carried out by using ${ }^{32} \mathrm{P}$-labeled VP5 promoter fragments from the wild type (w.t.) and mutant constructs. Nuclear extracts from infected HeLa cells were used (we have previously shown that uninfected and infected nuclear extracts give the same LBS complexes). Results of the first gel mobility shift is shown in Figure 7. As described previously (4), two major complexes were formed, complex A (of lower mobility) and complex B (of higher mobility), with the wt VP5 promoter and the mutant LBS/13/6 promoter fragments(Fig.7. lanes 2 and 6). However when 
wt VP5

A
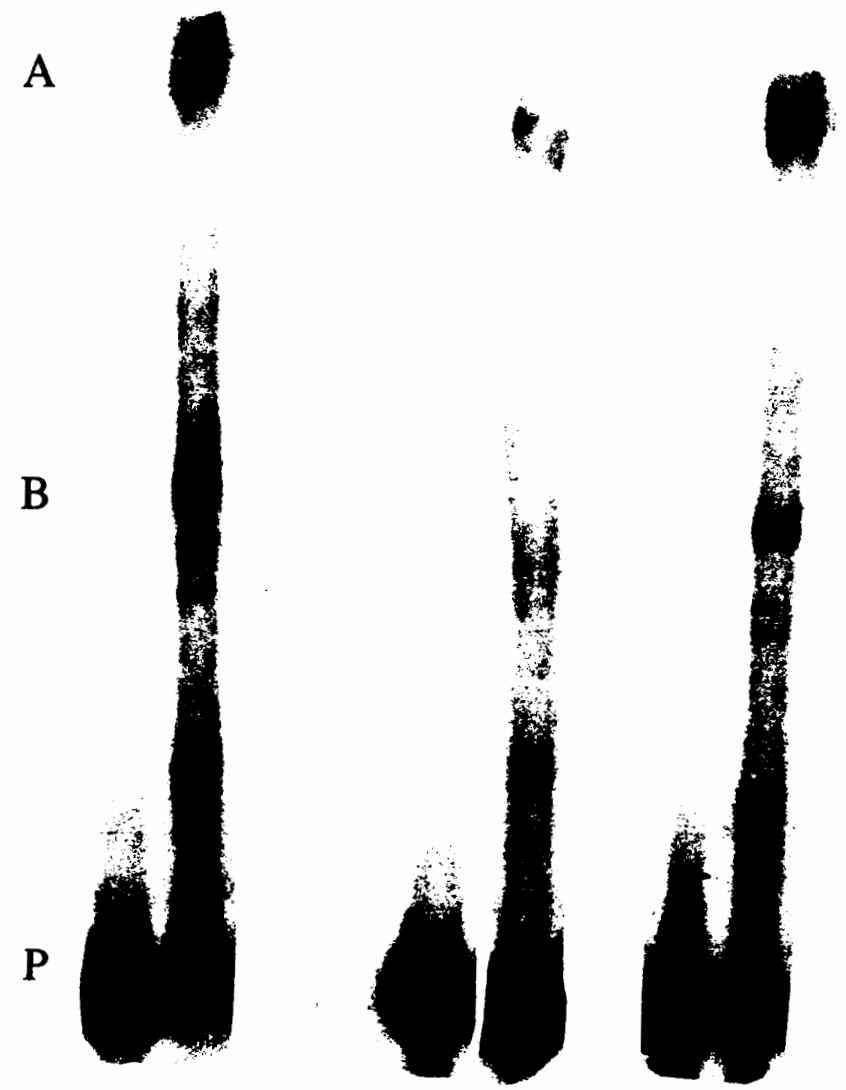

12

34

56

Fig.7 Gel mobility shift assay I. The data were described at the Table 3. Lanes 1, 3 and 5 were ${ }^{32} \mathrm{P}$ labeled promoter fragments from wt VP5, 13/6 and LBS/13/6. Lanes 2, 4 and 6 were same fragments incubated with the nuclear extract of the infected HeLa cells. Two complexes were formed, A and B, in lanes 2 and 6 . Electrophoretic mobility shift polyacrylamide gel $(4 \%)$ was run at 250 volts for 2 hours in nonrecirculating buffer.

" $\mathrm{A}$ " is the complex $\mathrm{A}$, " $\mathrm{B}$ " is the complex $\mathrm{B}$ and " $\mathrm{P}$ " is the probe. 
TABLE 3. Gel mobility shift assay I

\begin{tabular}{|c|cccccc|}
\hline & 1 & 2 & 3 & 4 & 5 & 6 \\
\hline wt VP5 probe & + & + & - & - & - & - \\
13/6 probe & - & - & + & + & - & - \\
LBS/13/6 probe & - & - & - & - & + & + \\
NE + polydIdC & - & + & - & + & - & + \\
\hline YY1 complex A Formed & - & + & - & - & - & + \\
YY1 complex B Formed & - & + & - & - & - & + \\
\hline
\end{tabular}

$\mathrm{NE}$ is the nuclear extract of the infected HeLa cells. PolydIdC is an unspecific DNA sequence to neutralize the unbinding NE proteins. There are six reactions, the first lanes 1,3 and 5 are ${ }^{32} \mathrm{P}$-labeled promoter fragments from wt VP5 (-4 to -168$), 13 / 6$ and LBS/13/6 probes only and the other three are incubated NE $(1 \mu \mathrm{g})$ with probes and polydIdC. Two complexes, called complex A and B, located at the middle and lower parts (lanes 2 and 6) and free probes (lanes 1, 3, 4, and 5) appeared. Electrophoretic mobility shift polyacrylamide gel (4\%) was run at 250 volts for 2 hours in $1 \mathrm{x}$ nonrecirculating buffer (see fig.7). 
deletion 13/6 (without YY1 binding site) was used, essentially no YY 1 complexes were formed (Fig.7. lane 4). The results of this experiment are summarized in Table 3. These results confirm that mutation $13 / 6$ lost the YY 1 binding site, and LBS/13/6 had regained it.

\section{B. Complexes A and B are formed by cellular factor YY1.}

To confirm that the complexes ( $A$ and $B)$ were indeed formed by $Y Y 1$ (LBF), the following competition gel mobility shift assays were performed. Oligonucleotide LBS, containing the YY1 binding site, or oligonucleotide $\mathrm{C}_{2}$ lacking the LBS sequence were added at 150 -fold molecular excess to the labeled probe $10 \mathrm{~min}$ before the nuclear extract was added. After 20 minutes of incubation at room temperature, the samples were analyzed by electrophoresis in $4 \%$ polyacrylamide gels ( methods described in Chapter III). The results showed that both the complex A and B seen with the wt VP5 and reinsertion LBS/13/6 promoter fragments were inhibited by the LBS oligonucleotide , but not by the oligonucleotide C2 (Fig.8). These results are summarized in table 4 . We can conclude from this experiment that both wt VP5 and reinsertion mutant, LBS $/ 13 / 6$, have a specific binding site for the cellular factor YY1, and this site is absent from mutation $13 / 6$.

\section{The binding of YY1 (LBF) is required for optimal transactivation of the wild-type VP5 promoter by superinfected HSV1.}

To compare the function of the mutant VP5 promoters with the wild type and to analyze the gene regulation function of complex A and complex B, the wt VP5, deletion of $13 / 6$, reinsertion of LBS/13/6 promoters were tested in transient expression assays for bacterial CAT (chloramphenical acetyl-transferase) gene expression. HeLa cells 
wt VP5

Las

A

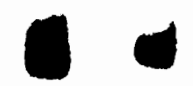

\section{$x$}

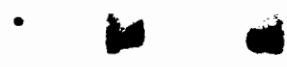

A

B
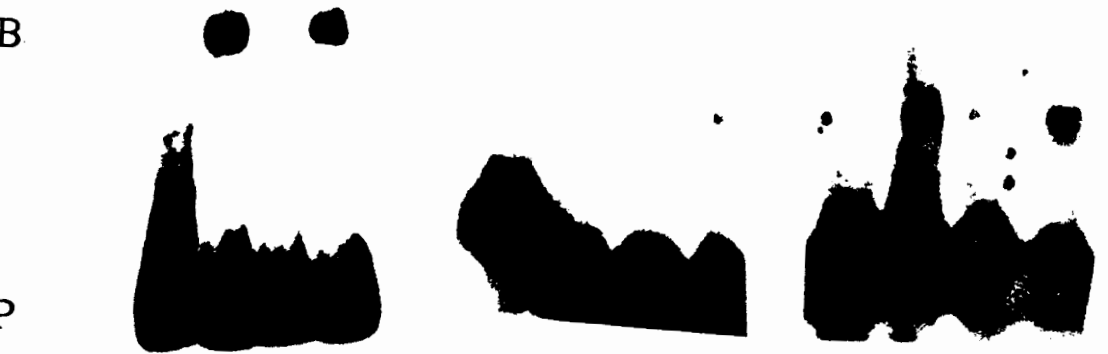

B

$\begin{array}{llll}1 & 2 & 3 & 4\end{array}$

$\begin{array}{llll}5 & 6 & 7 & 8\end{array}$

$\begin{array}{llll}9 & 10 & 11 & 12\end{array}$

Fig.8 Competition binding assay I. The description was at the Table 4. Lanes 1,5 and 9 without NE, all other lanes with NE 200-fold molar excess of LBS oligonucleotide was added to Lanes 3,7 and 11 . Oligonucleotide $C 2$ was added to the lanes 4,8 and 12 . 
TABLE 4 Competition binding assay I

\begin{tabular}{|c|c|c|c|c|c|c|c|c|c|c|c|c|}
\hline & 1 & 2 & 3 & 4 & 5 & 6 & 7 & 8 & 9 & 10 & 11 & 12 \\
\hline wt VP5 probe & + & + & + & + & - & - & - & - & - & - & - & - \\
\hline $13 / 6$ probe & - & - & - & - & + & + & + & + & - & - & - & - \\
\hline LBS/13/6 probe & - & - & - & - & - & - & - & - & + & + & + & + \\
\hline $\mathrm{NE}+$ polydIdC & - & + & + & + & - & + & + & + & - & + & + & + \\
\hline Oligo LBS & - & - & + & - & - & - & + & - & - & - & + & - \\
\hline Oligo C2 & - & - & - & + & - & - & - & + & - & - & - & + \\
\hline YY1 complex A Formed & - & + & - & + & - & - & - & - & - & + & - & + \\
\hline YY1 complex B Formed & - & + & - & + & - & - & - & - & - & + & - & + \\
\hline
\end{tabular}

Based on the tabel 3 data, this experiment is the further work to see if the complexes can be competitived by specific oligonucleotide LBS and C2. Oligonucleotide LBS is a specrific YY1 binding site. C2 is an another specific oligonucleotide without YY1 binding site. When LBS was added at 200 folds molar excess of probe, it forms the complexes with YY1 contained in NE without showing on the film, so complexes A and B were gone (lanes 3 and 11). But C2 can not bind YY1, so YY1 still binded to the LBS in the probes wt VP5 and LBS/13/6 (lanes 4 and 12). 
were transfected with $8 \mu \mathrm{g}$ of the three VP5 target plasmids, and twenty hours later they were superinfected with HSV1 (vhs-1). The cells were harvested 26 hours after superinfection and lysates were prepared and used for CAT enzyme assays. A pUC18 plasmid (lacking the CAT gene) was used as control in this experiment. The results are shown in Figure 9. If the wt VP5 CAT expression following superinfection is considered to be $100 \%$, the deletion $13 / 6$ reduced the CAT yield to $47.5 \%$ of the wild type level, and the reinsertion LBS/13/6 was reduced to $22.8 \%$. The CAT activity with pUC18 and all of the VP5 CAT plasmids without superinfection by HSV1 are approximately the same (about $1.0 \%$ relative to wt induced levels). This value is also about the same as that obtained with cells without transfected plasmids, i.e. background level.(Fig.9 and Table 5).

From these transient expression assay results, I conclude the following: (1) Deletion of YY1 binding site (LBS) produced a two-fold reduction in induced CAT activity. (2) Surprisingly, reinsertion of YY1 binding site ( the LBS oligonucleotide) did not restore the CAT activity, but further reduced it to 1/4 that of w.t. VP5. Additionally, based on the above results, it can be seen that during the transactivation event, not only YY1 but also viral factors perform important roles since all the CAT assays without HSV1 superinfection are almost at background level. Previous results from this laboratory and others indicated that the viral factors involved are the immediate early proteins, ICP4, 0 and 27.

\section{Project 2}

Project 2 involved designing and testing point mutations in the VP5 promoter. 


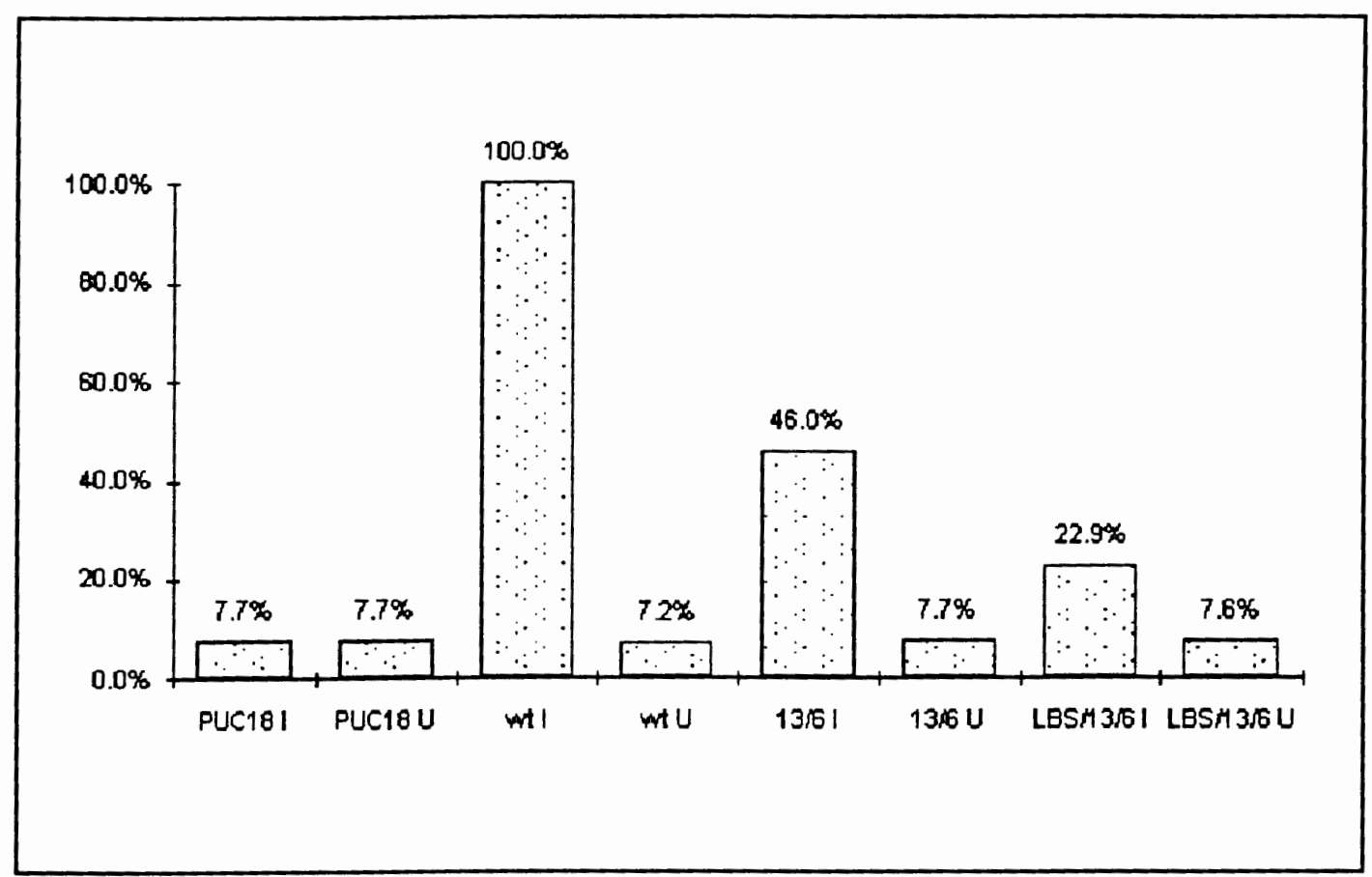

Fig. 9 Induction of transient VP5 promoter - CAT constructs I. In project 1, there are three plasmids compared each other: wt VP5, 13/6 in which LBS sequence was deleted and LBS/13/6 in which LBS was reinserted back to 13/6. This Fig. shows that if we consider wt VP5 CAT yield as $100 \%$, while the $13 / 6$ is $46.0 \%$ (S.D. is $15.2 \%$ ) and LBS/13/6 is $22.9 \%$ (S.D. is $12.0 \%$ ). The "I" means superinfection by HSV1 and the "U" means unsuperinfection. In this experiment, all the unsuperinfection cells' CAT assay were near the background. 
TABLE 5. Transient gene expression I

\begin{tabular}{|c|c|c|c|c|c|c|c|c|c|c|c|c|c|c|c|}
\hline \multirow[b]{2}{*}{$\begin{array}{l}\text { CAT } \\
\text { Assay }\end{array}$} & \multicolumn{4}{|c|}{ puc 18} & \multicolumn{3}{|c|}{ W.t } & \multicolumn{4}{|c|}{$13 / 6$} & \multicolumn{4}{|c|}{$\mathrm{LBS} / 13 / 6$} \\
\hline & $\overline{I^{a}}$ & $\begin{array}{c}\% \text { of } \\
w t^{c}\end{array}$ & $\mathrm{U}^{\mathrm{b}}$ & $\begin{array}{c}\% \text { of } \\
w t^{c}\end{array}$ & $I^{2}$ & $U^{b}$ & $\%$ of $w t^{c}$ & $\mathrm{I}^{\mathrm{a}}$ & $\begin{array}{l}\% \text { of } \\
w t^{c}\end{array}$ & $\mathrm{U}^{\mathrm{b}}$ & $\%$ of $w t^{c}$ & $I^{2}$ & $\begin{array}{l}\% \text { of } \\
w t^{c}\end{array}$ & $\mathrm{U}^{\mathrm{b}}$ & $\begin{array}{l}\% \text { of } \\
w t^{c}\end{array}$ \\
\hline 1 & 430 & $5.8 \%$ & 470 & $6.4 \%$ & 7353 & 453 & $6.2 \%$ & 4871 & $66.2 \%$ & 508 & $6.9 \%$ & 2909 & $39.6 \%$ & 491 & $6.7 \%$ \\
\hline 2 & 688 & $0.4 \%$ & 1554 & $1.0 \%$ & 155461 & 543 & $0.3 \%$ & 73192 & $47.1 \%$ & 510 & $0.3 \%$ & 17842 & $11.5 \%$ & 465 & $0.3 \%$ \\
\hline 3 & 205 & $10.7 \%$ & 210 & $10.9 \%$ & 1921 & 194 & $10.1 \%$ & 784 & $40.8 \%$ & 218 & $11.3 \%$ & 352 & $18.3 \%$ & 218 & $11.3 \%$ \\
\hline 4 & 497 & $14.0 \%$ & 437 & $12.3 \%$ & 3553 & 437 & $12.3 \%$ & 1062 & $29.9 \%$ & 435 & $12.2 \%$ & 787 & $22.2 \%$ & 404 & $11.4 \%$ \\
\hline
\end{tabular}

a. Superinfection briefly written. It is the CAT yield coming from the cells that were superinfected by HSV1.

b. Unsuperinfection briefly written. That is the CAT yield coming from the cells that were not superinfected by HSV1.

c. The percentage compared with superinfected wt VP5 CAT values.

This table is to show the radioactivity reading by the automatic equipment, the unit is $\mathrm{cpm}$. The result is from $24 \mu \mathrm{l}$ lysate that total amount is $100 \mu \mathrm{l}$, coming from $75 \mathrm{~cm}^{2}$ dish cells. Four times CAT assays have been done. According to this table, we get the average percentage of 13/6 CAT yield $46.0 \%$ (S.D. is $15.2 \%$ ) and LBS/13/6 CAT yield $22.9 \%$ (S.D. is $12.0 \%$ ) compared with wt VP5 that is considered as $100 \%$ CAT yield (see Fig.9). 
The goal of project 2 was to find out which base pairs are most important for viral transactivation. Two point mutations were designed (Chapter III), called mutation 1 (mut. 1) and mutation 2 (mut. 2). Mut. 1 has 3 base pairs changed at the 5 end of the LBS (YY binding site) and mut. 2 has 4 base pairs changed at the 3' end of the YY 1 site (Fig.11). These point mutations were verified by DNA sequencing( Fig. 12). All the techniques and experiments involved in project 2 were approximately same as project 1. The results are following:

\section{A. Mutations 1 and 2 both lost YY1 binding sites.}

Mutation 1 and 2 were tested in gel mobility shift assays for loss of YY1 binding (Fig. 13). These assays showed that both mut.1 and mut. 2 resulted in lost of the complex A completely (Fig. 13, lanes 5 and 6), and severe reduction in complex B (Fig. 13, lane 5 and 6 ). The data from this experiment are summarized in Table 6. These results indicate that both the distal GGCC and proximal TCCG are important for YY 1 function.

The Fig. 14 showed the competition gel mobility shift assay in mutation 2 .

\section{B. Different regions in LBS perform different function during V P 5 promoter transactivation for binding factor YY1.}

To test the function of mut. 1 and mut. 2, similar transient expression CAT assays were carried out as in project 1 . The results showed that both mut. 1 and mut.2 reduced the CAT activity induced by HSV1 super infection. However, the level of reduction for each mutation was not same. Mut. 1 reduced the CAT activity to $12.5 \%$ and mut. 2 reduced it only to $73.7 \%$ of wt levels(Fig. 15). The data summarizing this experiment are presented in Table 7. These results strongly suggest that different 

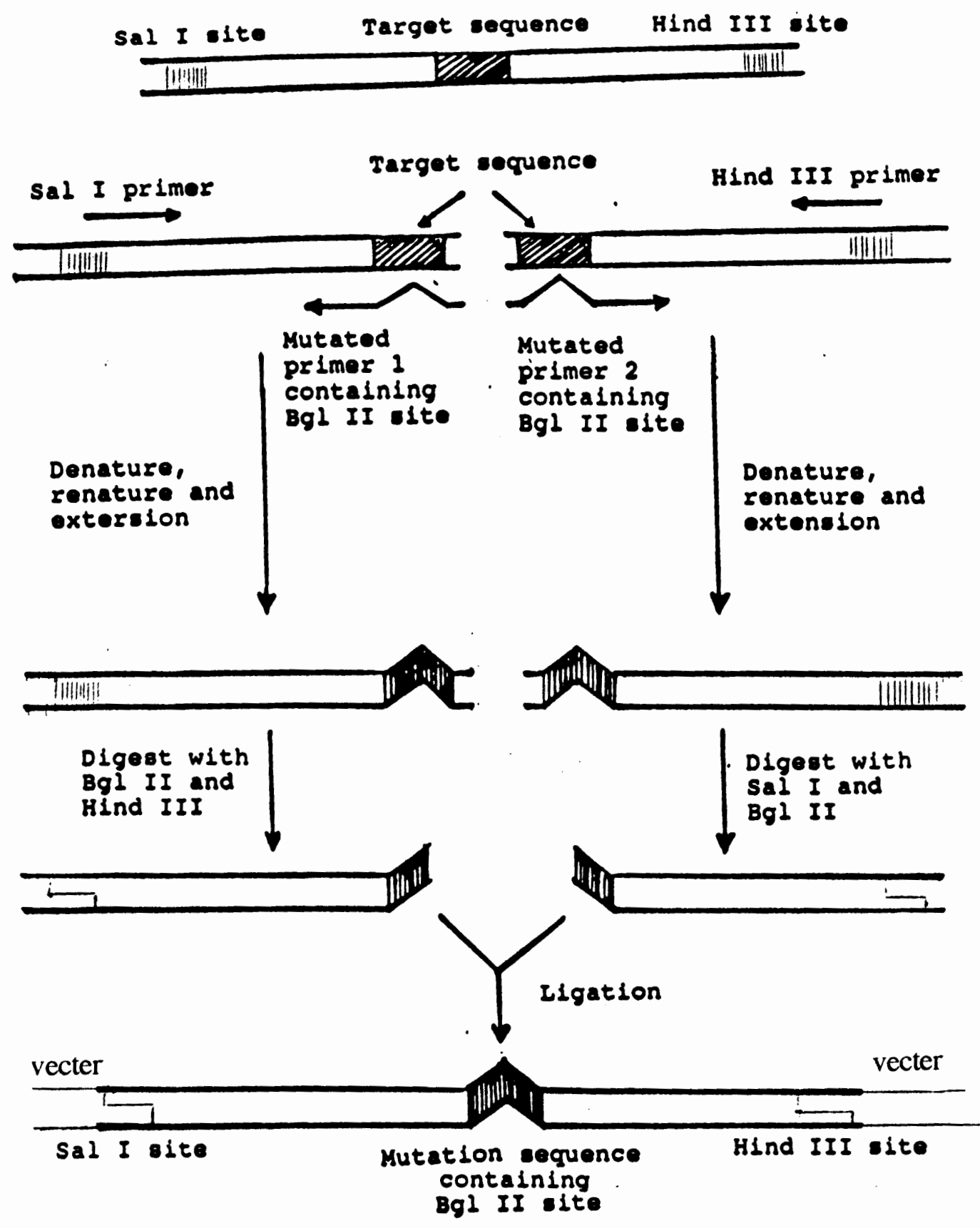

Fig. 10. Use of the PCR technique for the mutation 1 and 2.

This chart just shows one mutation forming procedure, but the principle is same. Bgl II is the designed primer to create a new fragment including Bgl II site that have two advantage: (1). It has mutated sequence. And (2), It will be very useful for the screening after transformation, because the VPS W.T. does not have Bgl II site. 
W.T.

Part of promoter

TCTTCCTGGC ACGCTTTTGG ACCAG CCC MCTMGATGC ACCCGTCGCG AGAAGGACCG TGCGAAACC TGGTC $-100$ $-90$ $-80$ $-60$

\section{Mutation 1}

TCTTCCTGGC ACGCTTTTG ACCAGAT T: AGAAGGACCG TGCGAAACC TGGTCTA AC ACACG TGGGAGCGC

\section{Mutation 2}

TCTTCCTGGC ACGCTTTTGG ACCAG 2 Bgl II

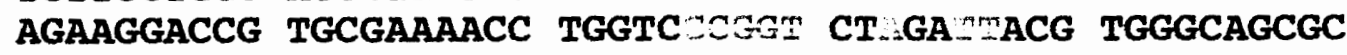

PCR: $\leftarrow$ BgIII $\rightarrow$ Hind $\|$ 


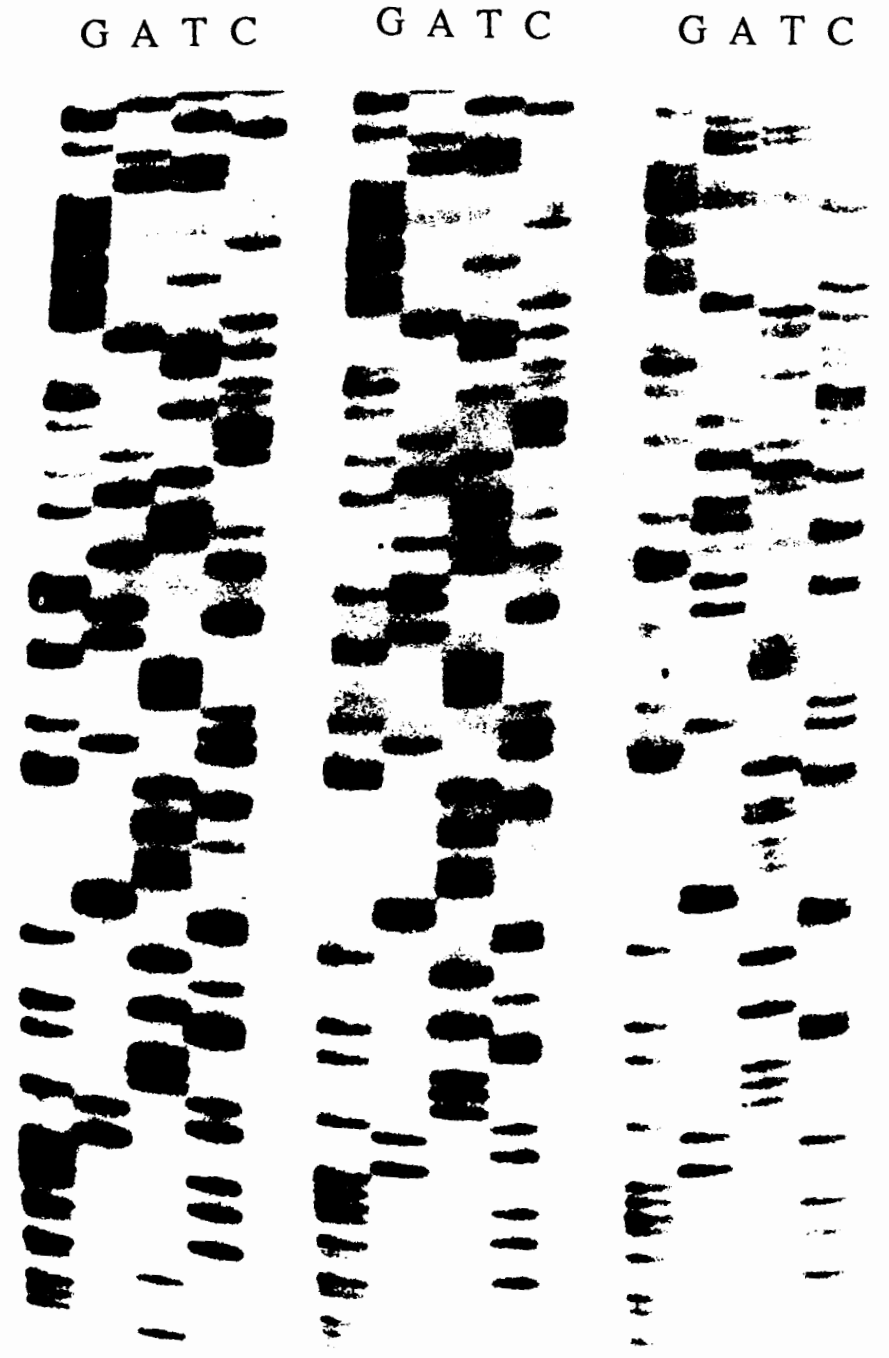

Fig.12 DNA sequence of point mutations. USB Kit was used in the DNA sequencing reaction. Compared with the wt VP5, mutation 1 has 3 base pairs difference and inutation 2 has 4 base pairs difference. The arrow region is the mutant part. The detailed description is in the chapter III. 
regions in LBS have different functions. Even though both regions are very important in forming the YY1-LBS complexs, the roles in gene expression of wt VP5 are not same.

\section{YY1 may interact with SP1 protein during wild type VP5 gene expression.}

It was noticed in gel mobility shift assays that there was a DNA-protein complex band of lower mobility above the complex A (Fig.14). Based on the construction of wt VP5 promoter used in these projects, a potential SP1 ( SP1 binding site located at the downsdream of YY1 binding site at around -40 bp relative to the mRNA start site) was speculated this complex band of lower mobility might be formed by SP1 binding. Therefore, I used an oligonucleotide containing an SP1 binding site as a competitor in the gel mobility shift assays. This resulted in the dissappearance of all the lower mobility band present in the gel mobility shift assays of wt.VP5, mut.1 and mut.2 promoters were gone (Fig.16, complex C). This results indicated that this lower mobility band was formed by Sp1-DNA binding. These results suggested that YY1 may interact with SP1 during wt VP5 transfection. 


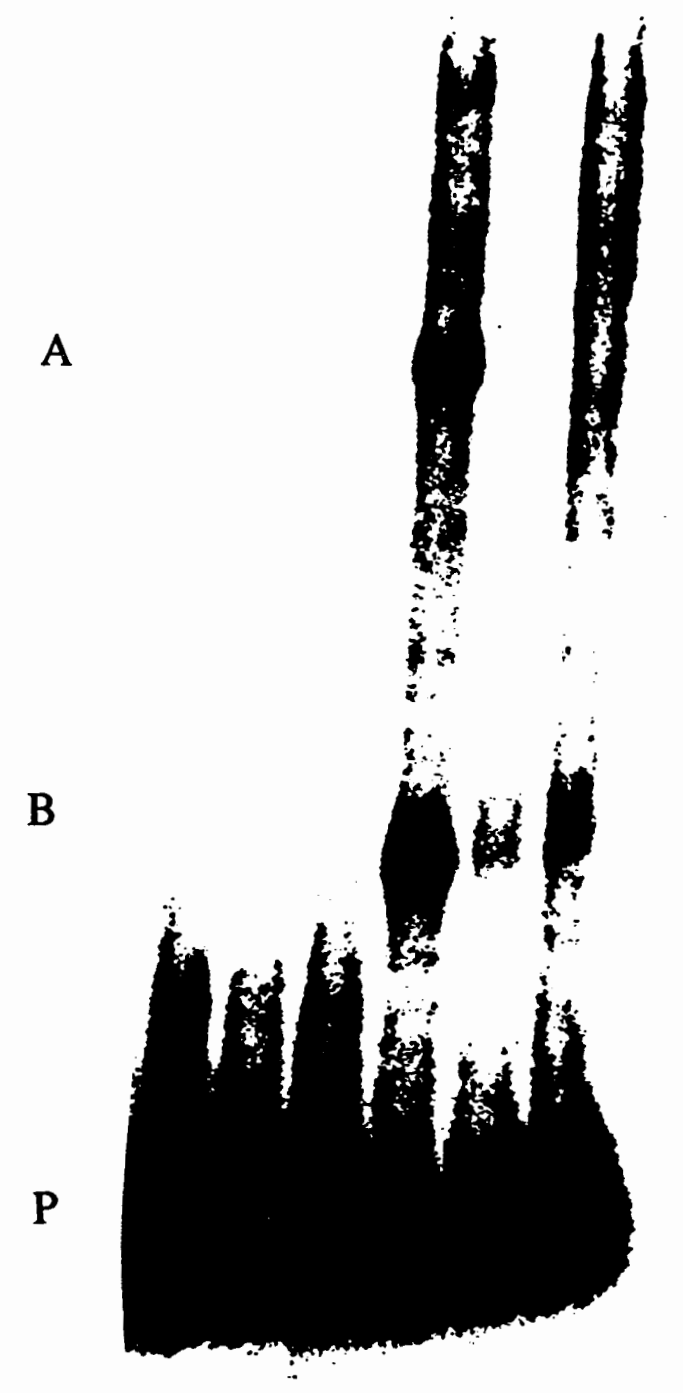

\section{$\begin{array}{llllll}1 & 2 & 3 & 4 & 5 & 6\end{array}$}

Fig.13 Gel mobility shift assay II. The data were described at the Table 6 . Lanes 1,2 and 3 were ${ }^{32} \mathrm{P}$ labeled promoter fragments from wt VP5, mut. 1 and mut. 2. Lanes 4, 5 and 6 were same fragments incubated with the nuclear extract of the infected HeLa cells. Two complexes were formed, $A$ and $B$, in lanes 4 and a very ligh band formed in lane 6 . Electrophoretic mobility shift polyacrylamide gel (4\%) was run at 250 volts for 2 hours in nonrecirculating buffer. 
TABLE 6. Gel mobility shift assay II

\begin{tabular}{|c|c|c|c|c|c|c|}
\hline & 1 & 2 & 3 & 4 & 5 & 6 \\
\hline wt VP5 probe & + & - & - & + & - & - \\
\hline Mut 1 & - & + & - & - & + & - \\
\hline Mut 2 & - & - & + & - & - & + \\
\hline NE + polydIdC & - & - & - & + & + & + \\
\hline YY1 complex A Formed & - & - & - & + & - & - \\
\hline YY1 complex B Formed & - & - & - & + & * & * \\
\hline
\end{tabular}

The condition of this experiment was same as project 1 (table 3), the only difference was using Mut. 1 and Mut. 2 fragments instead of the $13 / 6$ and LBS/13/6 fragments. The first three areprobes only and the rest three areincubated NE with probes and polydIdC.

The marker "*" indicates that there was a smear band located at the complex B location. This band looks like very light, the amount of Mut. is a little more than Mut. 2. 
$\underline{\text { wt VP5 }} \quad$ Mut. 1 Mut. 2

C

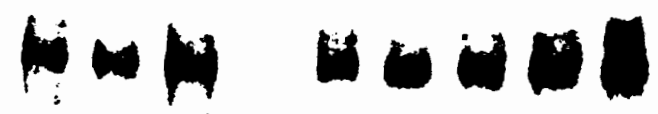

A

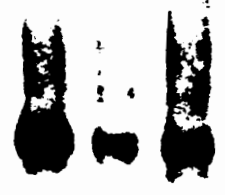

B
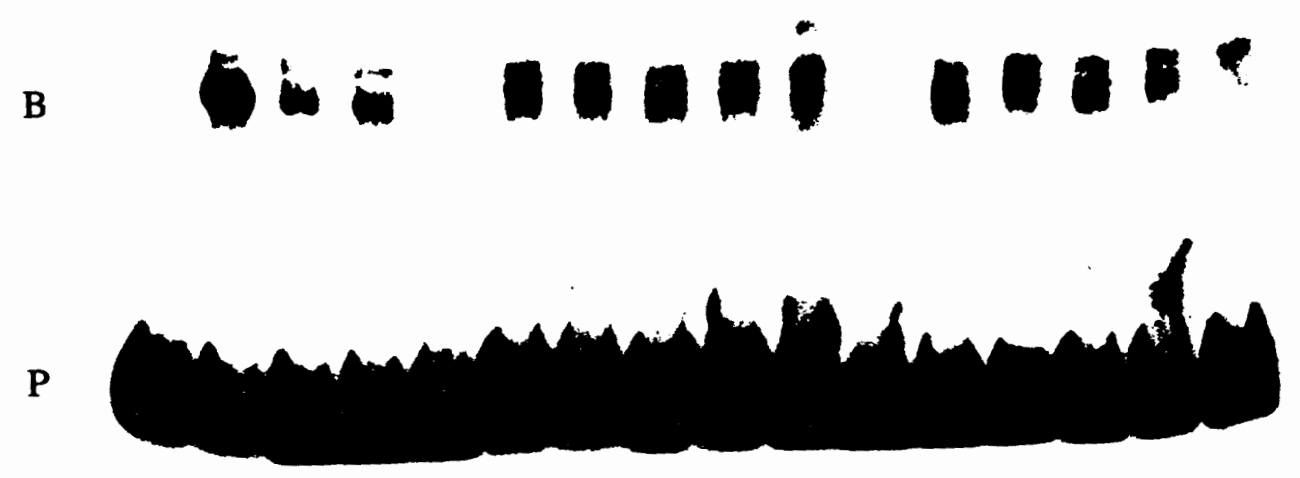

$\begin{array}{llllllllllllllll}1 & 2 & 3 & 4 & 5 & 6 & 7 & 8 & 9 & 10 & 11 & 12 & 13 & 14 & 15 & 16\end{array}$

Fig.14 Competition binding assay II. The description was at the Table 7. Lanes 1, 5 and 11 without NE, all other lanes with NE. 150-fold molar excess of LBS and C2 oligonucleotides were added to Lanes 7,13 and 814. 100-fold as probe of oligonucleotides CF1 and YY1 were added to lanes $3,9,15$ and $4,10,16$.

" $\mathrm{C}$ " is another complex. 
TABLE 7. Competition binding assay II

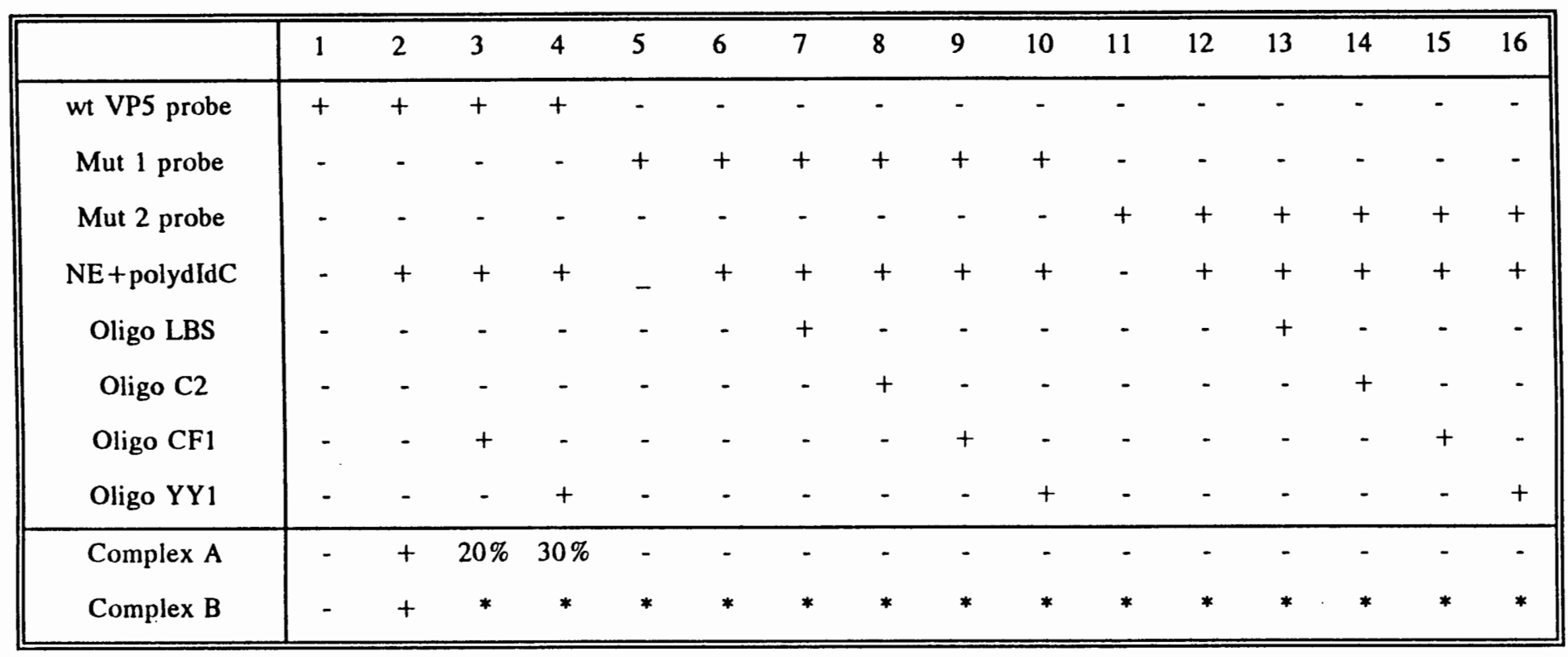

This work was the further experiment based on the gel mobility shift assay II. The marker "*" is same meaning as table 6. Both oligonucleotide CF1 and oligonucleotide YY1 have the DNA-protein binding sites. In this experiment, they are competiting with LBS contained in the probe, just like the function of oligonucleotide LBS. The amounts of oligonucleotide LBS and C2 were 150 folds as probe, oligonucleotide CF1 and YY1 are 100 folds as the probes. Lanes 3, 4 showed CF1 and YY1 binded most proteins, but not completely, still $20 \%$ and $30 \%$ left those binded the probe DNAs. 


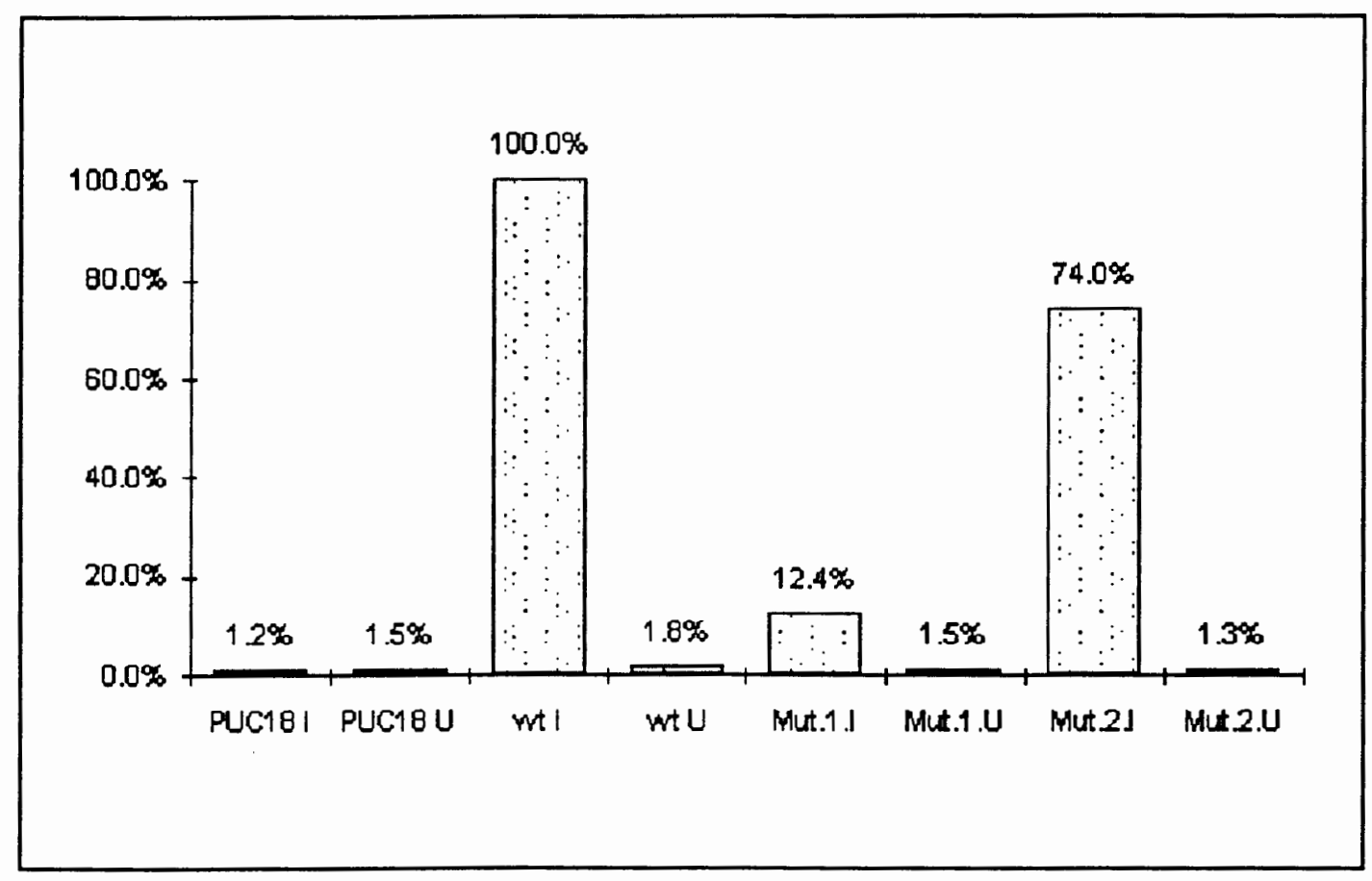

Fig. 15 Induction of transient VP5 promoter - CAT constructs II. In project 2, there are three plasmids compared each other: wt VP5, Mut. 1 in which LBS sequence was changed 3 bp different at the 5 " part and Mut. 2 that is 4 bp different at the 3' part. This Fig. shows that if we consider wt VP5 CAT yield as $100 \%$, while the Mut. 1 is $12.4 \%$ ( S.D. is $1.4 \%$ ) and Mut. 2 is $74.0 \%$ (S.D. is $3.8 \%$ ). The "I" means superinfection by HSV1 and the "U" means unsuperinfection. In this experiment, allthe unsuperinfection cells' CAT assay results were near the background. 
TABLE 8. Transient gene expression II

\begin{tabular}{|c|c|c|c|c|c|c|c|c|c|c|c|c|c|c|c|}
\hline \multirow[b]{2}{*}{$\begin{array}{l}\text { CAT } \\
\text { Assay }\end{array}$} & \multicolumn{4}{|c|}{ puc18 } & \multicolumn{3}{|c|}{ wt VP5 } & \multicolumn{4}{|c|}{ Mut.1 } & \multicolumn{4}{|c|}{ Mut.2 } \\
\hline & $\mathrm{I}^{\mathrm{a}}$ & $\begin{array}{c}\% \text { of } \\
w t^{c}\end{array}$ & $\mathrm{U}^{\mathrm{b}}$ & $\begin{array}{l}\% \text { of } \\
w t^{c}\end{array}$ & $I^{a}$ & $\mathrm{U}^{\mathrm{b}}$ & $\begin{array}{l}\% \text { of } \\
w t^{c}\end{array}$ & $I^{a}$ & $\begin{array}{l}\% \text { of } \\
w t^{c}\end{array}$ & $\mathrm{U}^{\mathrm{b}}$ & $\begin{array}{l}\% \text { of } \\
w t^{c}\end{array}$ & $\mathbf{I}^{\mathbf{a}}$ & $\begin{array}{c}\% \text { of } \\
w t^{c}\end{array}$ & $\mathrm{U}^{\mathrm{b}}$ & $\begin{array}{l}\% \text { of } \\
w t^{c}\end{array}$ \\
\hline 1 & 803 & $1.3 \%$ & 1173 & $1.9 \%$ & 62240 & 1234 & $2.0 \%$ & 7122 & $11.4 \%$ & 1152 & $1.9 \%$ & 47723 & $76.7 \%$ & 1022 & $1.6 \%$ \\
\hline 2 & 423 & $1.0 \%$ & 411 & $1.0 \%$ & 44450 & 693 & $1.6 \%$ & 5978 & $13.4 \%$ & 430 & $1.0 \%$ & 31697 & $71.3 \%$ & 450 & $1.0 \%$ \\
\hline
\end{tabular}

a. Superinfection briefly written. It is the CAT yield coming from the cells that were superinfected by HSV1.

b. Unsuperinfection. That is the CAT yield coming from the cells that were not superinfected by HSV1.

c. The percentage compared with superinfected wt VP5 CAT values.

The condition of this experiment was same as table 5. Two times CAT assays have been done.

According to this table, I get the average percentage of Mut.1 CAT yield $12.4 \%$ (S.D. is $1.4 \%$ ) and

Mut. 2 CAT yield $74.0 \%$ (S.D. is $3.8 \%$ ) compared with wt VP5 that is considered as $100 \%$ CAT yield (see Fig.15). 
wt VP5 Mut. $1 \quad$ Mut. 2

C

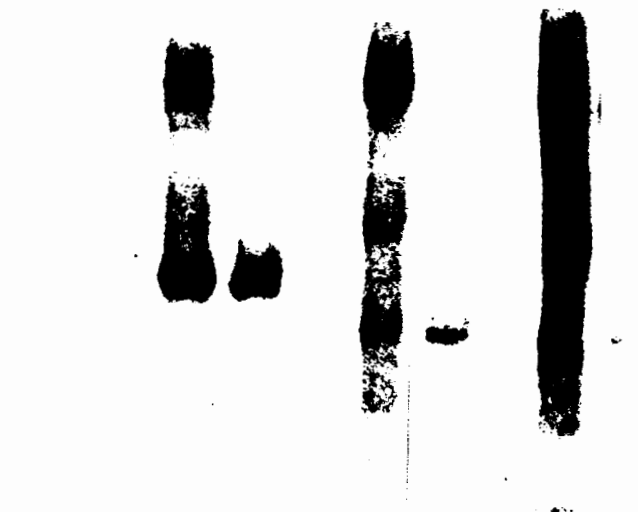

B

A
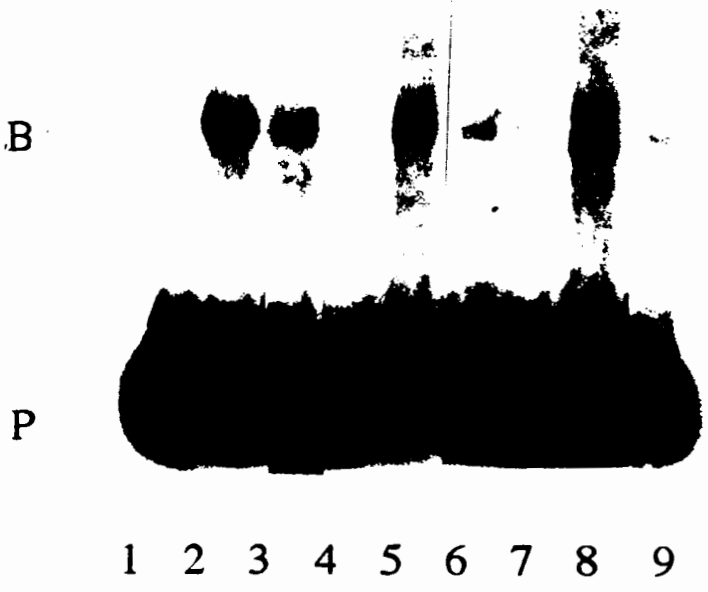

Fig.16 Competition binding assay III. Lanes 1, 4 and 7 without NE, all other lanes with NE. 120-fold molar excess of SP1 was added to Lanes3, 6 and 9. All the complexes $C$ were inhibited by the SP1 oligonucleotide. 


\section{CHAPTER V}

\section{DISCUSSION}

The results of my research in the past two and half years under the guidence of Dr. Robert L. Millette has shed some light onto the molecular mechanisms of how the transcription of the Herpes Simplex Virus Type 1 (HSV1) VP5 gene is regulated in human Hela cells. Based on my data and those obtained previously in Dr. Millette's laboratory, it has become clear now that the cis regulatory element, Leaky-late gene binding site (LBS), located within the first 164 base pairs (bp) promoter region of the VP5 gene is required for the maximal transcriptional activation of the VP5 gene in Hela cells. In addition, the LBS element has been shown to bind a cellular trans-acting factor in a sequence specific manner. Furthermore, seven nucleotides out of twelve in the LBS region, situated near $5^{\prime}$ end and $3^{\prime}$ end of LBS, are critical for both the binding of the transcription factor and overall promoter activity of the $164 \mathrm{bp}$ fragment. Evidence from both biochemical and immunological studies of my experiments and previous observation from this laboratory almost unequivocally indicated that the trans-acting factor interacting with the LBS cis element is very similar, if not identical, to the previously identified transcription factor, Ying-Yang 1 (YY1) (36). Interestingly, depending on the flanking sequences of the LBS element, the binding of YY1 onto LBS could play either positive or negative role in regulating VP5 gene expression.

The above results opened a whole new avenue for more detailed characterization of VP5 transcriptional regulation in Hela cells. Specifically, one can address the 
following questions: (1) Is YY1 the only protein that binds to the LBS site or there are other nuclear proteins binding to LBS? There have been many examples that one DNA binding site could be occupied by various proteins at different developmental stages or under different physiological conditions (30). In addition, recent experiments by $\mathrm{L}$. Mills have shown that, in the glycoprotein D promoter, YY1 and factor SP1 may compete for binding to overlapping sites. (2) Does YY1 interact with any other transcription factors in regulating VP5 promoter? For example, it is noticed there is a highly conserved Sp1 site located downstream of the LBS and previous experiments have shown that Sp1 site is required for the 164 bp VP5 promoter activity (36). Studies from Shenk's group have indicated that $\mathrm{Sp} 1$ and $\mathrm{YY} 1$ can interact direcly with each other to exert synergistic regulation of the GST-fusion proteins gene (29). Thus, it is conceivable that YY1 can also interact with Sp1 on VP5 promoter to regulate its expression. (3) Is this binding protein the same YY1 as previouly identified by Shi and Shenk (39,) or is it a related isof rom? (4) Is the expression or activity of YY1 regulated by herpes simplex virus infection? The significance and feasibility of addressing these questions as well as the analyses of the experimental results are discussed in details as follows.

\section{A. The LBS site activates VP5 gene expression by binding to a cellular factor(s).}

Previous studies have shown that a 9 bp element, LBS, within the $164 \mathrm{bp}$ promoter region in the VP5 gene is required for the full activity of the $164 \mathrm{bp}$ promoter. Even though the sequences of the LBS element showed high degree of similarity to those of the previously characterized transcription factor YY1 and Sp1, there was little known about the trans-acting factors that interact with LBS. In order to identify and 
characterize the putative transcription factors that interact with LBS, gel mobility shift assays were first carried out. When the Hela nuclear extract was incubated with a 164 bp fragment containing the LBS site, three DNA-proteins complexes could be detected (A, B and C). Deletion of the LBS from the same fragment completely abolished the formation of A and B DNA-protein complexes, which stronly implicate the role of these DNA-protein complexes in regulating VP5 transcription (mutation 13/6, Fig.7). When the LBS sequences were ligated back into the same fragment, the formation of the A and B DNA-protein complexes were fully restored. Therefore, the binding of these nuclear proteins to the VP5 promoter is specific for the presence of LBS. Interestingly, point mutations at certain loci of the LBS element specifically abolished the formation of the $A$ and $B$ complexes, while the binding of band $C$ was unaffected (Fig. 14). Transient expression assays showed that these point mutations decreased the promoter activity significantly (Fig.15). These results indicated that complexes A and B were recognized by different cellular factors then complex $\mathrm{C}$ was, which suggests that they are different factors; (2) the forming of complexes $\mathrm{A}$ and $\mathrm{B}$ are functionally required for the expression of VP5.

\section{B. The protein that forms the complexes A and B with the LBS element is closely related, if not identical, to the YY1 transcription factor while the factor that forms the complex $\mathrm{C}$ may be related to Sp1 transcription factor.}

Since the first $164 \mathrm{bp}$ of VP5 promoter contains a YY1 like element and Sp1 like element, a series of experiments were carried out to determine whether the proteins that form the complexes A, B and C are related to YY1 or Sp1. By a number of criteria (binding competition, partial proteolysis, and monoclonal antibody assays), the proteins 
that forms complexes A and B appear to be closely related to, if not identical to, the previously identified transcription factor YY1 (36). An oligonucleotide containing the consensus binding site of SP1 could efficiently compete away the complex C from w.t. VP5 probe, indicating this cellular factor may be related to SP1 factor (Fig.16). The fact that endogenous SP1 can bind to the downstream consensus SP1 site raises the question of whether the endogenous SP1 is also involved in the regulation of VP5 transcription. Especially, SP1 and YY1 have been shown to co-regulate a number of genes (30), it is possible that these factors interact with each other on the VP5 promoter in the activation of VP5 transcription. To test the possibility, the first step would be to determine whether mutation of the downstream SP1 site will affect the VP5 promoter activity. If SP1 factor is involved in the regulation, then the following experiments could be proposed to determine whether YY1 and SP1 function synergistically by directly interacting with each other. (1) One can perform immuno co-precipitation with antibody agains either the endogenous SP1 or YY1 to detect the putative in vivo SP1/YY1 complex. (2) One can also carry out co-transfection assays to over-express either YY1 and VP5/CAT, SP1 and VP5 or YY1/SP1/VP5. If YY 1 and SP1 function synergistically, overexpression of both YY1 and SP1 should lead to higher expression of CAT from the VP5 164 bp promoter than any single of these. Since the endogenous SP1 activity in Hela cells is quite high overexpression of the exogenous SP1 may not show any further activaiton. This potential problem could solved by using a Drosophila Melanogaster cell line which has almost no detectable SP1 activity.

\section{Depending on the flanking sequences, the binding of YY1 to the YY1 site in the VP5 promoter could result in either a positive or negative control of VP5 transcription.}


When the YY1 site with three additional base pairs at the $5^{\prime}$ end and six at the $3^{\prime}$ end of was added to the YY1 deleted VP5 promoter, the promoter activity was decreased by five fold compared to the wild type promoter (Fig.9). Supprisingly, the level of binding of YY1 to the added YY1 site was identical to that of wild type. The YY1 factor, however, has been shown to have dual regulatory property: it could either activate or suppress transcription of certain genes (53). Even though the additional nine base pairs added to either $3^{\prime}$ or 5 ' end of YY1 site did not change the binding efficiency, it could very well change the three demensional relationships of the YY1 protein sitting on VP5 promoter to other VP5 transcription factors including SP1. This is especially important in light of recent results showing that YY1 can bend DNA to effect a positive or negtive control. In order to fully understand VP5 transcriptional regulation the above possibility should be further explored by future experiments. The same experiments described as above can be carried out to determine whether YY1 and SP1 still interact with each other at presence of the same additional base pairs. Furthermore, the possible alterations of either YY1 or SP1 domanis involved in the interacting can be studied by various biochemical techniques, e.g. chemical cross linking studies. The interacting domains can then be studied in greater detail by site directed mutagenesis. Hopefully, in the long run, this study will provide scientific bases for clinical application. One possibility is one might be able to disrupt the functional interaction of YY1 and SP1 by introducing either YY1 or SP1 interacting domain only to compote with the endogenous holloprotein.

\section{The nucleotides of YY1 site are not equally important for VP5 promoter activity.}

At the resolution of gel mobility shift assays, I could not distinguish Mutation 1 
from Mutation 2 with regarding to the efficiency of disrupting binding; the promoter activities of both mutations varied profoundly (Fig. 15). Mutation 1 reduced CAT expression to $12.5 \%$ of wild type whereas Mutation 2 only to $73.5 \%$. One possible explanation to this puzzling phenomenum is that there is still some residual binding of YY1 to Mutant 2 YY1 site which is below the detectable level of gel mobility shift assays. This explanation could be tested by more sensitive titration competition assays where the wild type YY1 site will be used as the probed and various amounts of Mutant 1 and Mutant 2 YY 1 site will be used as the competitors. It is worth noting, however, that other laboratories have also found that nucleotides at the 5' end of YY1 site appear to be more important than those near the $3^{\prime}$ end.

\section{E. Additional future experiments for completely understanding the mechanism of how HSV1 is regulated.}

It is still not completely clear whether the YY1 is the only factor interacting with the VP5 YY 1 site or whether the YY1 we detected in Hela cells is exactly the same as previously characterized one. To sort this out, one can perform methylation interference assay to determine whether the contact points of YY1 on VP5 match previous results. And it is also worth searching for different isoforms of YY 1 in Hela cells using either low stringecy screening or PCR technique.

It would be interesting to study whether the expression of the endogenous YY1 or SP1 is regulated at the infection of HSV1. Since it is clear that YY1 and SP1 are involved in regulating a number of cellular genes, to understand the interplay of HSV1 and the endogenous YY1 and SP1 may help to understand not only how HSV1 infection may indirectly manifest its pathogenesis but also how the infection change the host cell metabolism. 


\section{REFERENCES}

1. Bauknecht, T,.P. Angel et al. 1992. Identification of negative regulatory domain in the human papillomavirus type 18 promoter: interaction with the transcriptional repressor YY1. The EMBO Journal 11: 4067-4617.

2. Blair, E. D., and E. K. Wagner. 1986. A single regulatory region modulates both cis activation and trans activation of the herpes simplex virus VP5 promoter in transient expression assays in vivo. J. Virol. 60:460-469.

3. Cai, W., and P. A. Schaffer. 1989. Herpes simplex virus type 1 ICPO plays a critical role in the de novo synthesis of infectious virus following transfection of viral DNA. J. Virol. 63:4579-4589.

4. Chen, S., L.Mill et al. 1992. Transactivation of Major Capsid Protein Gene of Herpes Simplex Virus Type 1 Requires a Cellular Transcription Factor. J.Virol. 66:4304-4314.

5. Costa, R. H., K. G. Draper, G. Devi-Rao, R. L. Thompson, and E. K. Wagner. 1985. Virus-induced modification of the host cell in required for expression of the bacterial chloramphenicol acetyltransferase gene controlled by a late herpes simplex virus promoter (VP5). J. Virol. 56:19-30.

6. DeLuca, N. A., and P. A. Schaffer. 1985. Activation of immediate-early, early, and late promoters by temperature-sensitive and wild-type forms of herpes simplex virus type 1 protein ICP4. Mol. Cell. Biol. 5: 1997-2008.

7. Dennis, D., and J. R. Smiley. 1984. Transactivation of a late herpes simplex virus promoter. Mol. Cell. Biol. 4:544-551.

8. Dignam, D., R. M. Ledowitz, and R.G. Robert. 1983. Accurate transcription initiation by RNA polymerase II in asoluble extract from isolated mammalian nuclei. Acids. Res. 11:1475-1489.

9. Dixon, R. A. F., and P. A. Schaffer. 1980. Fine structure mapping and functional analysis of temperature-sensitive mutants in the gene encoding the herpes simplex virus type 1 immediate-early protein VP175. J. Virol. 6:189-203.

10. Dretzen, G., M. Bellard, P. Sassone-Corsi, and P. Chambon. 1981. A reliable method for the recovery of DNA fragments from agarose and acrylamide gels. Anal. Biochem. 112:295-298.

11. Dulbecco, R and H. Ginsberg. 1988. Virology. Second edition. N.Y.

12. Everett, R. D. 1984. A detailed analysis of an HSV1 early promoter: sequences involved in transcativation by viral immediate-early gene products are not earlygene specific. Nucleic Acids Res. 12:3037-3056. 
13. Everett, R. D. 1984 . Transactivation of transcription by herpes-virus products: requirements for two HSV1 immediate early polypeptides for maximum activity. EMBO J. 3:3135-3141.

14. Everett, R. D. 1986. The products of herpes simplex virus type 1(HSV1) immediate-early genes 1,2 and 3 can activate HSV 1 gene expression in trans. J. Gen. Virol. 68:2507-2513.

15. Flanagan, W. M., A. G. Papavassiliou, M. Rice, L. B. Hecht, S. Silverstein, and E. K. Wagner. 1991. Analysis of the herpes simplex virus type 1 promoter controlling the expression of UL38, a true late gene involved in capsid assembly. J. Virol. 65:769-786.

16. Garner, M. M., and A. Revzin. 1981. A gel electrophoresis method for quantifying the binding of proteins to specific DNA regions: application to components of the E. coli lactose operon regulatory system. Nucleic Acids Res. 9:3047-3060.

17. Godowski, P. J., and D. M. Knipe. 1986. transcriptional control of herpesvirus gene expression: gene functions required for positive and negative regulation. Proc. Natl. Acad. Sci. USA 83:256-260.

18. Gorman, C. M., L. F. Moffat, and B. H. Howard. 1982. Recombinant genomes which express chloramphenicol acetyltransferase in mammalian cells. Mol. Cell. Biol. 2:1044-1051.

19. Gualberto, A. et al. 1992. Functional antagonism between YY1 and the serum response factor. Mol.Cell. Biol. 12:4209-4214.

20. Harris-Hamilton, E., and S. L. Bachemheimer. 1985. Accumulation of herpes simplex virus type 1 RNAs of different kinetic classes in the cytoplasm of infected cells. J. Virol. 53:144-151.

21. Holland, L., K. Anderson, C. Shipman, Jr., and E. Wagner. 1980. Viral DNA synthesis is required for the efficient expression of specific HSV1 mRNA species. Virology 101:10-24.

22. Honess, R. W., and B. Roizman. 1974. Regulation of herpesvirus macromolecular synthesis. I. Cascade regulation of the synthesis of three groups of viral proteins. J. Virol. 14:8-19.

23. Honess, R. W., and B. Roizman. 1975. Regulation of herpesvirus macromolecular synthesis: sequential transition of polypeptide synthesis requires functional viral polypeptides. Proc. Natl. Acad. Sci. USA 72:1276-1280.

24. Hou, Y. 1990. Molecular Virology. B.J.

25. Johnson, P. A., and R. D. Everett. 1986. The control of herpes simplex virus type 1 late gene transcription: A TATA-box'/cap site region is sufficient for 
fully efficient regulated activity. Nucleic Acids Res. 14:8247-8264.

26. Jones, P., and B. Roizman. 1979. Regulation of herpesvirus macromolecular synthesis. VIII. The transcription program consists of three which both extent of transcription and accumulation of RNA in are regulated. J. Virol. 31:299-314.

27. Kuwabara, M., and D. Sigman. 1987. Footprinting DNA-protein complexes in situ following gel retardation assays using 1,10-phenanthroline- copper ion: Escherichia coli RNA polymeraselac promoter complexes. Biochemistry 26:7234 7238.

28. Kwong, A. D., and N. Frenkel. 1988. Herpes simplex virus type- 1 infected cells contain a function(s) that stabilizes both host and viral mRNAs. Proc. Natl. Acad. Sci. USA 84:1926-1930.

29. Lee, T., Y. Shi and R.J. Schwartz. 1992. Displacement of BrdUrd-induced YY 1 by serum response factor activates skeletal $\alpha$-actin transcription in embryonic myoblaste. Proc. Natl. Acad. Sci. USA. 89:9814-9818.

30. Lee, J.,K.M. Galvin and Y. Shi. 1993. Evidence for physical interaction between the zinc-finger transcription factors YY1 and Sp1. Pro. Natl. Acad.Sci. USA 90:6145-6149.

31. Maniatis, T., J. Sambrook, and E.G. Fritsch. 1989. Molecular cloning, a laboratory manual, 2nd ed. Cold Spring Harbor Laboratory Press, Cold Spring Harbor, N.Y.

32. McCarthy, A. M., L. McMahan, and P. A. Schaffer. 1989. Herpes simplex virus type 1 ICP27 deletion mutants exhibit altered patterns of transcription and are DNA deficient. J. Virol. 63:18-27.

33. McGeogh, D. J., M. A. Dalrymple, A. J. Davison, A. Dolan, M. C. Frame, D. McNab, L. J. Perry, J. E. Scott, and P. Taylor. 1988. The complete sequence of the long unique region in the genome of herpes simplex virus type 1. J. Gen. Virol. 69:1531-1574.

34. McGeogh, D. J., A. Golan, S. Donald, and F. J. Rixon. 1985. Sequence determination and genetic content of the short unique region in the genome of herpes simplex virus type 1. J. Mol. Biol. 181:1-13.

35. Millette, R. L., and R. Klaiber. 1980. Gene expression of herpes simplex virus. II. UV radiological analysis of viral transcription units. J. Virol. 34:604614.

36. Mills, L.and R. L, Millette. 1994. YY1 is the Cellular Factor Previously to Bind the Certain Leaky-late Genes of Herpes Simplex Virus Type 1. J. Virol. 66: 1234-1240.

37. Natesan, S. and M.Z. Gilman. 1993. DNA bending and orientation- 
dependent function of YY1 in the c-fos promoter. Gen Devel. 7:2497-2509.

38. Nordeen, S. K., P. P. Green III, and D. M. Fowlkes. 1987. A rapid, sensitive and inexpensive assay for chloramphenicol acetyltransferase. DNA 6:173-178.

39. Park, K. and M.L. Atchison. 1991. Isolation of a candidate repressor/activator, NF-E1 (YY -1, $\delta$ ), that binds to theimmunoglobulin $\kappa$ 3' enhencer and the immunoglobulin heavy-chain $\mu \mathrm{E} 1$ site. Proc. Natl. Acad. Sci USA 88 :9804-9808

40. Pedersen, M. M., S. Taley-Brown, and R. L. Millette. 1981. Gene expression of herpes simplex virus. III. Effect of arabinosyladenine on viral polypeptide synthesis. J. Virol. 38:712-719

41. Perry, L. J., F. J. Rixon, R. D. Everett, M. C. Frame, and D. J. McGeogh. 1986. Characterization of the IE1 10 gene of herpes simplex virus type 1. J. Gen. Virol. 67:2356-2380.

42. Preston, C. M. 1979. Abnormal properties of an immediate-early polypeptide in cells infected with the herpes simplex virus mutant defective in virion-associated shutoff. J. Virol. 46:498-512.

43. Read, G.S. and N. Frenkel. 1983. Herpes simplex viru smutant defective in virion-associated shutoff. J. Virol. 46:498-512.

44. Rice, S. A., and D. M. Knipe. 1988. Gene-specific transactivation of herpes simplex virus 1 alpha protein ICP27. J. Virol. 62:3814-3823.

45. Rice, S. A., and D. M. Knipe. 1990. Genetic evidence for two distinct transactivation functions of the herpes simplex virus $\alpha$ protein ICP27. J. Virol. 64:1704-1715.

46. Riggs, K.J. and S. Saleque, et al. 1993. Yin-Yang-1 activates the c-myc promoter. Mol. Cell. Biol. 13:7487-7495.

47. Roizman, B., and A. E. sears. 1990. Herpes simplex viruses and their replication, p. 1795-1841. In B. Fields and D. Knipe (ed.), Fields virology, 2nd ed. Raven Press, New York.

48. Roizman, B., R. J. Whitley and C.Lopez. 1993. The herpesviruses. Second edition. 1-8.

49. Rouse,B.T. and C. Lopez. 1984 Immunobiology of Herpes Simplex Virus Infection. Boca Raton, Florida.

50. Sacks, W. R., C. C. Greene, D. P. Aschman, and P. A. Schaffer. 1985. Herpes simplex virus ICP27 is an essential regulatory protein. J. Virol. 55:796-805. 
51. Sekulovich, R. E., K. leary, and R. M. Sandri-Goldin. 1988. the herpes simplex virus type 1 protein ICP27 can act as a trans-repressor or a transactivator in combination with ICP4 and ICPO. J. Virpl. 62:4510-4522.

52. Seto, E., B.Lewls and T. Shenk. 1993. Interaction Between Transcription Factors Sp1 and YY1. Nature 365: 462-464.

53. Seto, E. Y. Shi and T. Shenk. 1991. YY1 is an initiator sequence-binding protein that directs and activates transcription in vitro. Nature. 354: 241-248.

54. Shelton, L. S. G., M. N. Pensiero, and F. J. Jenkins. 1990. Identification and characterization of the herpes simplex virus type 1 protein encoded by the UL37 open reading frame. J. Virol. 64:6101-6109

54. Shi, Y., E. Seto, L. S. Chang, and T. Shenk. 1991. Transcriptional repression by YY 1, a human GLI-Kruppel-related protein, and relief of repression by adenovirus E1A protein. Cell. 67:377-388.

55. Shi, Y. and E. Seto et al. 1991. Transcriptional repression by YY1, a human GLI-Kruppel-Related protein and relief of repression by adenovirus E1A protein. Cell. 67:377-388.

56. Shrivastava,A. et al. 1993. Inhibition of transcriptional regulator Yin-Yang-1 by association with c-myc. Science. 262:1889-1993.

57. Smith, I. L., M. A. Hardwicke, and M. Sandri-Goldin. 1992. Evidence that the herpes simplex virus immediate rarly protein ICP27 acts post-

transcriptionally during infection to regulate gene expression. Virology 186:74-86.

58. Su, L., and D. M. Knipe. 1989. Herpes simplex virus $\alpha$ protein ICP27 can inhibit or augment viral gene transactivation. Virology 170:496-504.

59. Wagner, E. K. 1985 Individual HSV transcipts: Characterization of specific genes, p.45-104. In B. Roizman. Herpesviruses, vol. 3. Plenum Press, New York.

60. Watson, R. J., and J. B. Clements. 1978. Characterization of transcriptiondeficient temperature-sensitive mutants of herpes simplex virus type 1. Vrology 91:364-379.

61. Weinheimer, S., and S. L. McKnight. 1987. Transcriptional and posttranscriptional controls establish the cascade of herpes simplex virus protein synthesis. J. Mol. Biol. 195:819-8.

62. Zhang, Y. F., G. B. Devi-Rao, M. Rice, R. M. Sandri-Goldin, and E. K. Wagner. 1987. The effect of elevated levels of herpes simplex virus $\alpha$ gene products on the expression of model early and late genes in vivo. Virology 157:99-106. 


\section{THE FUNCTIONS OF YY1}

I. Repressor in:

1. Adeno-associated virus (AAV) P5 promoter

2. Immunoglobulin (Ig) k $3^{\prime}$ enhancer

3. c-fos promoter

4. Human papilloma virus-18 promoter

5. Skeletal a-actin promoter

6. long terminal repeat of Moloney leukemia virus

II. Activator in:

1. c-myc promoter

2. IgH intronic enhencer

3. Promoters of ribosomal proteins $\mathrm{L30}$ and $\mathrm{L32}$

III. Initiator at nucleotide position +1 in the AAV P5 promoter 